\title{
Functional attributes of epilithic diatoms for palaeoenvironmental interpretations in South-West Greenland lakes
}

\author{
Suzanne McGowan (D) Hazel V. Gunn • Erika J. Whiteford • N. John Anderson • \\ Vivienne J. Jones $\cdot$ Antonia C. Law
}

Received: 5 July 2016/Accepted: 28 April 2017/Published online: 9 June 2017

(C) The Author(s) 2017. This article is an open access publication

\begin{abstract}
Benthic diatoms are commonly used for palaeoenvironmental reconstruction in Arctic regions, but interpretation of their ecology remains challenging. We studied epilithic diatom assemblages from the shallow margins of 19 lakes from three areas (coastinland-ice sheet margin) along a climate gradient in Kangerlussuaq, West Greenland during two periods; shortly after ice-off (spring) and in the middle of the growth season (summer). We aimed to understand the distribution of Arctic epilithic diatoms in relation to water chemistry gradients during the two seasons, to
\end{abstract}

S. McGowan $(\bowtie) \cdot$ H. V. Gunn

School of Geography, University of Nottingham,

University Park, Nottingham NG7 2RD, UK

e-mail: suzanne.mcgowan@nottingham.ac.uk

\section{S. McGowan}

School of Geography, University of Nottingham, Malaysia Campus, 43500 Semenyih,

Selangor Darul Ehsan, Malaysia

E. J. Whiteford · N. John Anderson

Department of Geography, Loughborough University,

Loughborough LE11 3TU, Leicestershire, UK

\section{J. Jones}

Environmental Change Research Centre, Department of Geography, University College London, Gower Street, London WC1E 6BT, UK

A. C. Law

School of Physical and Geographical Sciences, Keele University, William Smith Building,

Keele Staffs ST55BG, UK investigate their incorporation into lake sediments and to assess their applicability as palaeoenvironmental indicators. Diatoms were correlated with nutrients in the spring and alkalinity/major ions in the summer, when nutrients were depleted; approximately half of the variance explained was independent of spatial factors. When categorised by functional attributes, diatom seasonal succession differed among regions with the most obvious changes in inland lakes where summer temperatures are warmer, organic nutrient processing is prevalent and silicate is limiting. These conditions led to small, motile and adnate diatoms being abundant in inland lakes during the summer (Nitzschia spp., Encyonopsis microcephala), as these functional attributes are suited to living within complex mats of non-siliceous microbial biofilms. Seasonal succession in silica-rich lakes at the coast was less pronounced and assemblages included Tabellaria flocculosa (indicating more acidic conditions) and Hannaea arcus (indicating input from inflowing rivers). The nitrogen-fixing diatom Epithemia sorex increased from the coast to the ice sheet, negatively correlating with a gradient of reactive nitrogen. The presence of this diatom in Holocene sediment records alongside cyanobacterial carotenoids during arid periods of low nitrogen delivery, suggests that it is a useful indicator of nitrogen limitation. Nitzschia species appear to be associated with high concentrations of organic carbon and heterotrophy, but their poor representation in West Greenland lake sediments due to taphonomic processes limits their 
palaeoenvironmental application in this region. Proportions of epilithic taxa in lake sediment records of coastal lakes increased during some wetter periods of the Holocene, suggesting that snowpack-derived nutrient delivery may offer diatom taxa living at lake margins a competitive advantage over planktonic diatoms during the "moating" ice melt period. Thus, further research investigating linkages between epilithic diatoms, snowpack and nutrient delivery in seasonally frozen lakes is recommended as these taxa live on the 'front-line' during the spring and may be especially sensitive to changes in snowmelt conditions.

Keywords Arctic - Biofilm - Climate - Taphonomy · Nitrogen-limitation $\cdot$ Seasons $\cdot$ Snowmelt

\section{Introduction}

Diatom assemblages in lake sediments are commonly used as palaeoenvironmental indicators in Arctic regions (Bradley et al. 1996; McGowan et al. 2003; Jones and Birks 2004; Smol et al. 2005; Wolfe et al. 2006; Perren et al. 2012). Effective interpretation of diatom records requires ecological information which is commonly obtained via surface sediment "training sets", to determine correlations among diatoms and physical/chemical properties of lakes and define optimum and tolerance ranges for individual taxa (Ryves et al. 2002; Antoniades et al. 2005a; Michelutti et al. 2006; Lim et al. 2001a; Michelutti et al. 2007a). Extracting meaningful ecological information from Arctic training sets is challenging because environmental gradients are generally short, with low concentrations of nutrients and major ions. Training sets that span ecotonal boundaries usually record greater variability in physicochemical properties which correlate with catchment vegetation, but strong covariability among lake variables limits the ecological information that can be extracted (Bouchard et al. 2004; Lim et al. 2007; Juggins 2013). Most primary production in Arctic lakes occurs in benthic areas (Vadeboncoeur et al. 2003) and so training sets which correlate pelagic measurements with diatom assemblages have resulted in poorly defined ecological preferences for many benthic taxa (Antoniades et al. 2005a; Bonilla et al. 2005; Finkelstein and Gajewski 2008).
An alternative "back to basics" method for interpreting diatom records is to use qualitative or semiquantitative limnological or ecological knowledge of diatoms to interpret assemblage changes. Increases in small Cyclotella species are frequently used as indicators of changes in thermal stratification related to warming (Ruhland et al. 2008), because their abundance increases when lake stratification depth decreases (Saros et al. 2016). In High Arctic ponds, changes in the benthic diatom flora after the 18th century are interpreted as a response to warming, with longer ice-free periods expanding the colonisation of mosses and associated diatom epiphytes (Douglas et al. 1994). Such interpretations are more straightforward when environmental changes cause abrupt step changes in lake habitat availability (e.g. stronger stratification, development of aquatic plants). However, in lakes where no thresholds have been crossed and environmental changes are subtle, as is the case in many Arctic sites, this approach has limitations (Michelutti et al. 2007a). Investigating benthic diatoms within individual habitat types can help to define substrate preferences (e.g. sediment biofilms, sediment grains, plants, moss, or rock) and increase the understanding of benthic community structure, enabling greater information to be extracted from the benthic algal record (Michelutti et al. 2003; Pizarro et al. 2004).

Epilithic diatoms grow on rock substrates, and may include associations of attached, motile, epiphytic algae (attached to algal filaments) and facultatively planktonic taxa. Rock substrates are generally inert (but see Blinn et al. 1980) and exposed to a broad range of environmental stressors, and therefore epilithic diatoms are considered to be sensitive bioindicators of environmental conditions (King et al. 2006). Epilithon surveys show that diatoms change across gradients of nutrient (nitrogen, phosphorus) availability (King et al. 2000, 2006) and lake water pH (Cameron et al. 1999; Štefková 2006). Many other factors may influence epilithic diatom assemblages, e.g. invertebrate grazers, wave disturbance, UVR exposure and competition from non-diatom biofilm taxa (Bothwell et al. 1994; Kelly et al. 2009; Miller et al. 1992). However, diatoms which grow at the margins of annually frozen lakes live in "front-line" habitats, the first to receive nutrients and ions (e.g. sulphates) delivered in pulses during snowmelt as lake ice 'moating' progresses 
during the spring (Douglas and Smol 1999; Catalan et al. 2002; Quesada et al. 2008). It seems likely therefore, that littoral diatom assemblages might be highly responsive to the quantity, chemical composition and timing of snow melt. Patterns of Arctic epilithic community succession are not well understood, but it appears that diatom growth peaks early in the growth season (Moore 1974), further highlighting the importance of conditions during the spring. Better understanding of inter-seasonal differences is necessary to fully interpret lake sediment records which integrate diatom production from all seasons.

On death or detachment, epilithic diatoms are transported away from rocks and deposited together with diatoms from other habitats to form part of the lake sediments. The proportion of littoral epilithic diatoms in sediment records is partly dependent on lake bathymetry, which influences the proportion of lake benthos, including stone surfaces, exposed to light (Stone and Fritz 2006). Water level changes also cause major shifts in the proportion of benthic taxa in sediment records, especially in morphometrically uneven lake basins (Anderson and Battarbee 1994; Stevens et al. 2006). Alternatively, changing environmental conditions might shift the relative proportions of diatoms incorporated from different parts of the lake, e.g. some Arctic lakes which are ice covered for longer periods into the summer have proportionally fewer plankton (Keatley et al. 2008). Increases in water clarity associated with anthropogenic acidification or tree line retreat which reduces terrestrial inputs of coloured dissolved organic carbon expand the relative proportion of benthic production (Jones et al. 2011). As well as processes within the lake which alter relative diatom production, modification of the diatom assemblage occurs during and after the deposition in sediments (Ryves et al. 2013). Such taphonomy processes can be influenced by lake physical and chemical characteristics (Ryves et al. 2006), and because epilithic diatoms must be transported considerable distances before deposition in the sedimentary record at the lake centre they might be especially susceptible to damage, dissolution and washout from the lake (Cameron 1995). Despite this complexity, shifts in the abundance of epilithic diatoms are often observed in sedimentary assemblages and the challenge is to better interpret what they mean.
Here we investigated littoral epilithic diatom assemblages in different seasons (spring, summer) in a set of 19 lakes in the Kangerlussuaq area of West Greenland. The lakes span a climate gradient across a transect from the coast to ice sheet margin, and have well studied limnology exhibiting differences in water chemistry, length of ice-free season, snowpack, hydrological connectivity and maximum growth season temperatures. We first used traditional multivariate techniques to explore correlations among epilithic diatoms and water chemistry parameters across the region during each season with partial ordinations to determine whether spatial factors significantly influenced the results. Then, we compared functional attributes of diatoms to understand biofilm community structure differences between spring (early after ice-off) and summer periods. Next, we aimed to determine how well epilithic diatoms were represented in lake sediment records and whether this varied across the lake district. Finally, we tested the application of epilithic diatoms as palaeoenvironmmental indicators in this region where Holocene palaeoclimate and associated environmental changes are relatively well understood by re-visiting some previously published diatom records to determine whether we could extract further information from them.

\section{Methods}

Site description

The $180 \mathrm{~km}$ transect along Kangerlussuaq is the widest ice- free margin in Greenland, with over 15,000 lakes (Fig. 1) (Anderson and Stedmon 2007). A climate gradient along the transect spans a dry continental Low Arctic climate at the ice sheet margin (annual temperature range of -20 to $10{ }^{\circ} \mathrm{C} ;<150 \mathrm{~mm}$ precipitation year $^{-1}$ ) to increasingly maritime conditions at the coast (annual temperature range of -16 to $6{ }^{\circ} \mathrm{C} ;>500 \mathrm{~mm}$ precipitation year ${ }^{-1}$ ). To investigate changes in biota along this climate gradient, 19 freshwater lakes were selected from three main areas along the transect: (1) the coast (close to the town of Sisimiut but above the marine limit), (2) inland (close to the town of Kangerlussuaq) and (3) the ice sheet margin within a few kilometres of the ice sheet but not directly receiving glacial meltwater (Fig. 1). Ice melt 


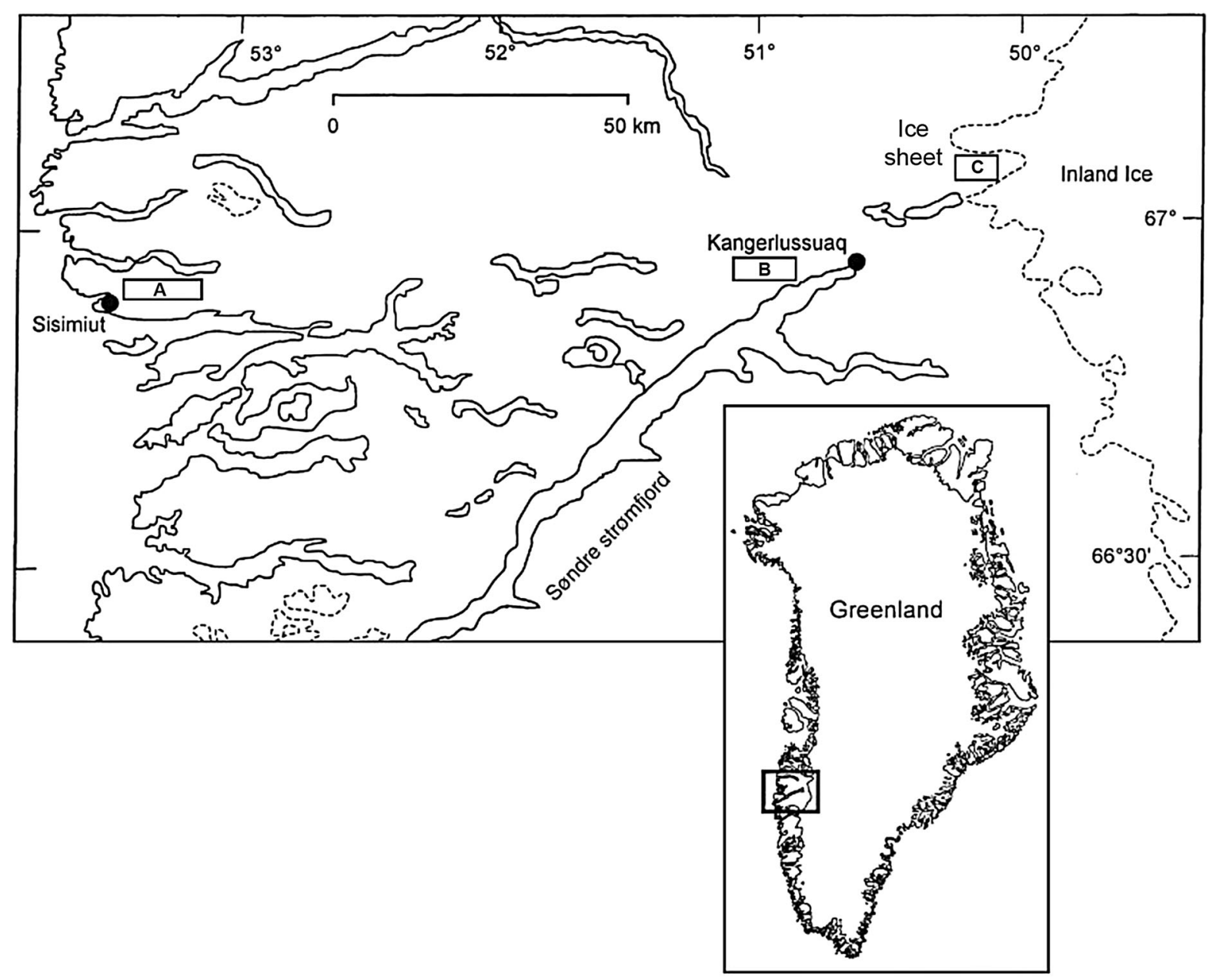

Fig. 1 Map of the Kangerlussuaq region revised from Whiteford et al. (2016) showing the location of the three study areas a coast, b inland and $\mathbf{c}$ ice sheet margin highlighted in black boxes with dots representing the closest human settlements

usually occurs at the start of June in the inland lakes, slightly later at the ice sheet lakes (which are cooled by katabatic winds) and more than two-three weeks later at the coast, where snow cover is three times greater and spring temperatures rise more slowly and so lakes may be 'moated' for several weeks (Whiteford et al. 2016). Lakes in the coastal area are generally connected to perennial stream networks which flow during the ice-free period whereas lakes in the inland and ice sheet regions are mostly hydrologically isolated because of the scarcity of precipitation. Lakes ranged in depth from 3 to $37 \mathrm{~m}$ and area from 4 to 38 ha and were formed mainly by glacial action scraping out basins, resulting in variable morphometries (Table 1).
Sample collection

Epilithic diatoms were collected from rocks in 19 lakes across the three areas during the mid-summer of 2010 (late July to early August) and the period immediately following ice-off in Spring 2011 (late June to early July) (Table 1). Collection dates across the region in spring reflect the order in which the ice melted from each area (inland- ice sheet margincoast) and samples were collected at coastal lakes whilst remnants of ice remained in the centre of lakes. Diatoms were sampled and combined from five approximately fist-sized (about 100-200 mm diameter) submerged rocks $<3 \mathrm{~m}$ from the edge at a water depth of around $50 \mathrm{~cm}$, removed using a soft brush and 


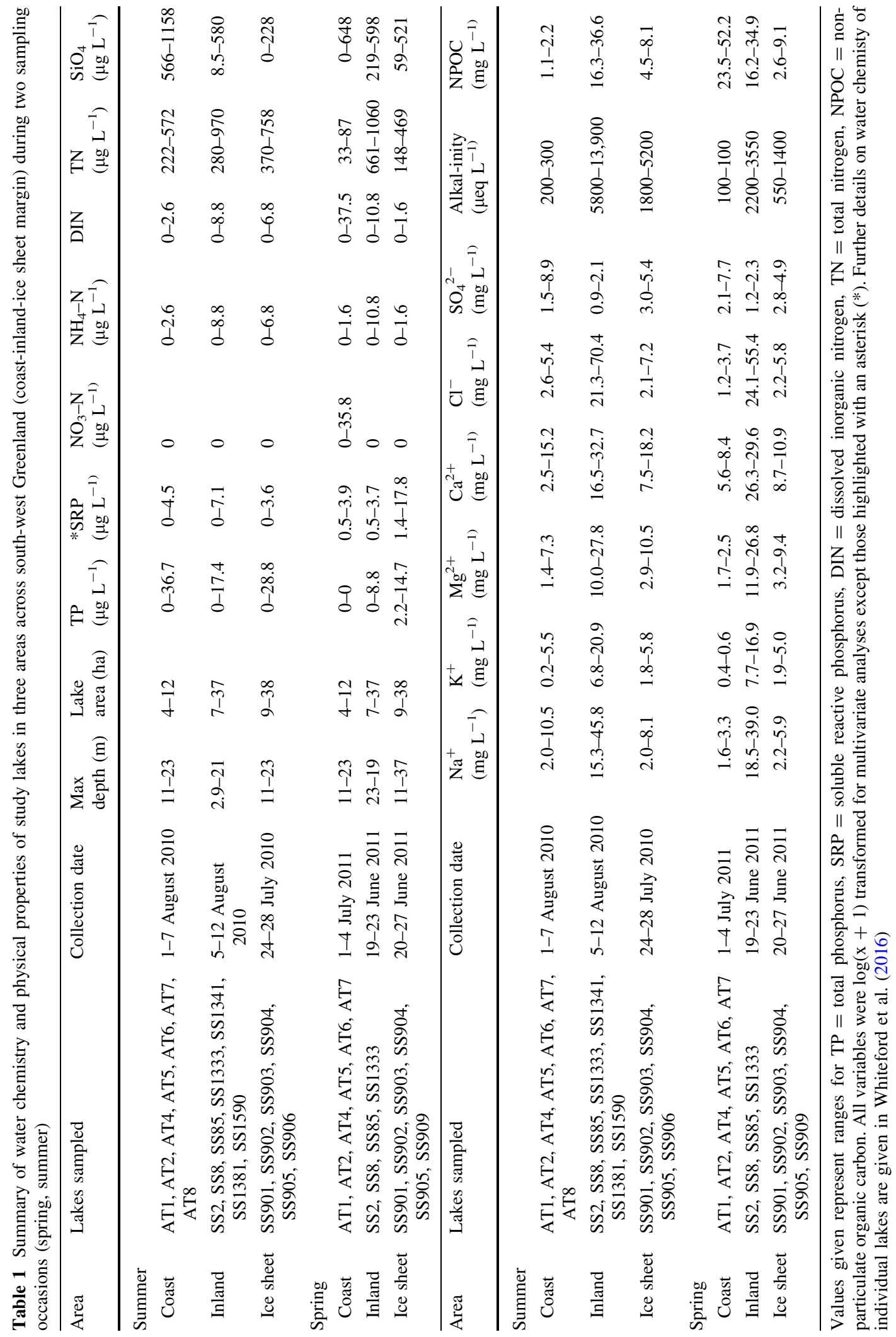


preserved with Lugol's iodine (King et al. 2006). Diatom slides were prepared following digestion with hydrogen peroxide and mounted using Naphrax resin following Battarbee et al. (2001). A minimum of 300 diatom valves per slide was counted using a Leica DME light microscope at $1000 \times$ magnification. Epilithic diatoms were identified with reference to Krammer and Lange-Bertalot (1986-1991) and online resources (Kelly et al. 2005; Spaulding et al. 2010). Each taxon was given a code used in numerical analyses and the most recent nomenclature and authorities are given in Table 2.Diatom counts were converted to percentage relative abundance for further analysis.

Lake water was collected for chemical analysis concurrent with the diatom samples and, in addition, a further sampling for water chemistry was conducted from under the lake ice in April 2011 (Whiteford et al. 2016). The mean of these three samples was calculated for each lake to provide an overview of regional differences in water chemistry. This water chemistry dataset has been previously published in Whiteford et al. (2016), but here we include only values from the lakes sampled for epilithon, which is a subsample of the broader survey. Water chemistry sampling and analysis followed standard procedures as detailed in Hogan et al. (2014).

\section{Numerical analyses}

Patterns in water chemistry across the sampling transect were explored using principal components analysis (PCA) of the mean water chemistry data. Data were first checked for homogeneity of variance and transformed if necessary (indicated in Table 1). PCA and other ordinations were performed on CANOCO version 5 (Ter Braak and Smilauer 2012). Diatom assemblages along the transect were explored for each sampling occasion (Spring 2011, Summer 2010) using detrended correspondence analysis (DCA), after establishing that axis 1 gradient lengths exceeded 2.5 SD and thus unimodal analysis was appropriate (Leps and Smilauer 2003). Canonical correspondence analysis (CCA) was used to analyse relationships between diatom taxa and water chemistry variables; in this analysis we paired diatoms with water chemistry values sampled on the same occasion, performing independent analyses for summer 2010 and Spring 2011. Because the sampling was focused in three distinctive regions, we included a measure of spatial autocorrelation in a partial CCA to evaluate the influence of spatial structure on the overall analysis (Borcard et al. 1992). A Principal Coordinates of Neighbour Matrices (PCNM) analysis of the UTM site coordinates was used to summarise spatial patterns in the data (Dray et al. 2006). Because almost all lakes in the dataset are hydrologically disconnected from one another, a more sophisticated network analysis was unnecessary (Blanchet et al. 2008). The variance partitioning with PCNM feature of CANOCO version 5 was used with manual forward selection (1000 Monte Carlo permutations) being used to establish which principal coordinates were significantly correlated with the diatom data (in this case the second principal coordinates axis PCO2). PCO2 was then used as a covariable in a partial CCA with manual forward selection to eliminate the chemical variables that were not significantly correlated with the diatoms $(p<0.05)$. Variables with the highest variance inflation factors (VIF) were sequentially removed from the partial ordination until all VIFs were $<21$ (Hall et al. 1999). The final analyses with the remaining environmental variables were displayed as a CCA to understand patterns among species and environmental factors, and then as a partial CCA with variance partitioning analysis (VPA) to determine the proportion of variance explained by environmental, spatial or both (environmental + spatial) components.

Diatom assemblage structure was explored by calculating richness (total number of taxa per sample) and diversity using the Shannon-Weiner diversity index where zero denotes minimum diversity. The ecological characteristics of all diatoms at $\geq 2 \%$ abundance were quantified with reference to Kelly et al. (2005) and Spaulding et al. (2010). Diatoms were characterised as follows based on growth habits; (1) planktonic (acknowledging that presence in the epilithon is probably caused by settling of planktonic taxa, but that some taxa can live in both benthic and planktonic habitats), (2) potential ablility to fix atmospheric nitrogen through symbiotic cyanobacterial associations (DeYoe et al. 1992), (3) prostrate (grows lying flat on the rock surface), (4) solitary (usually grows alone, but recognizing that some diatoms are able to grow both alone or in colonial form), and (5) moderately motile (not including 


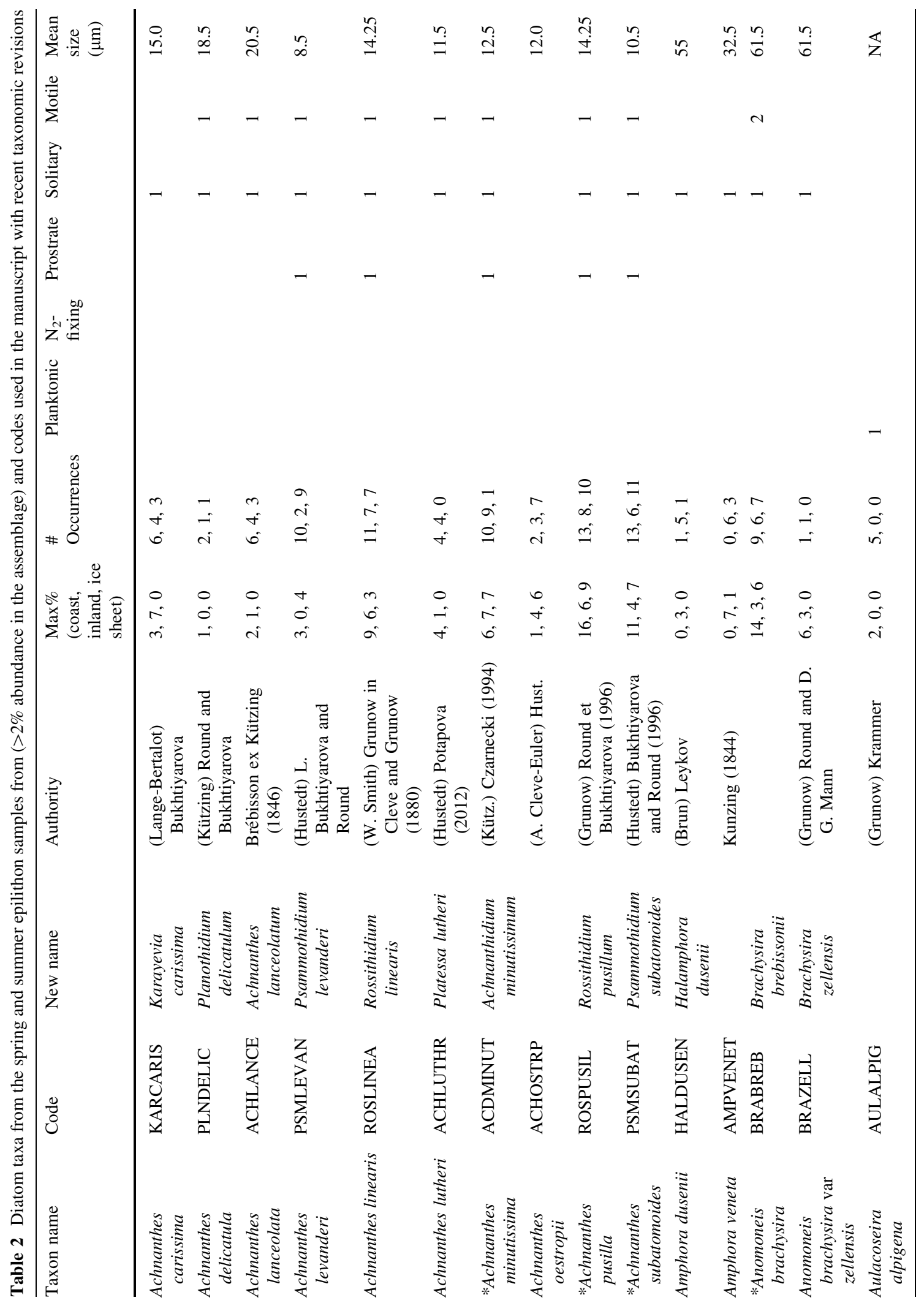




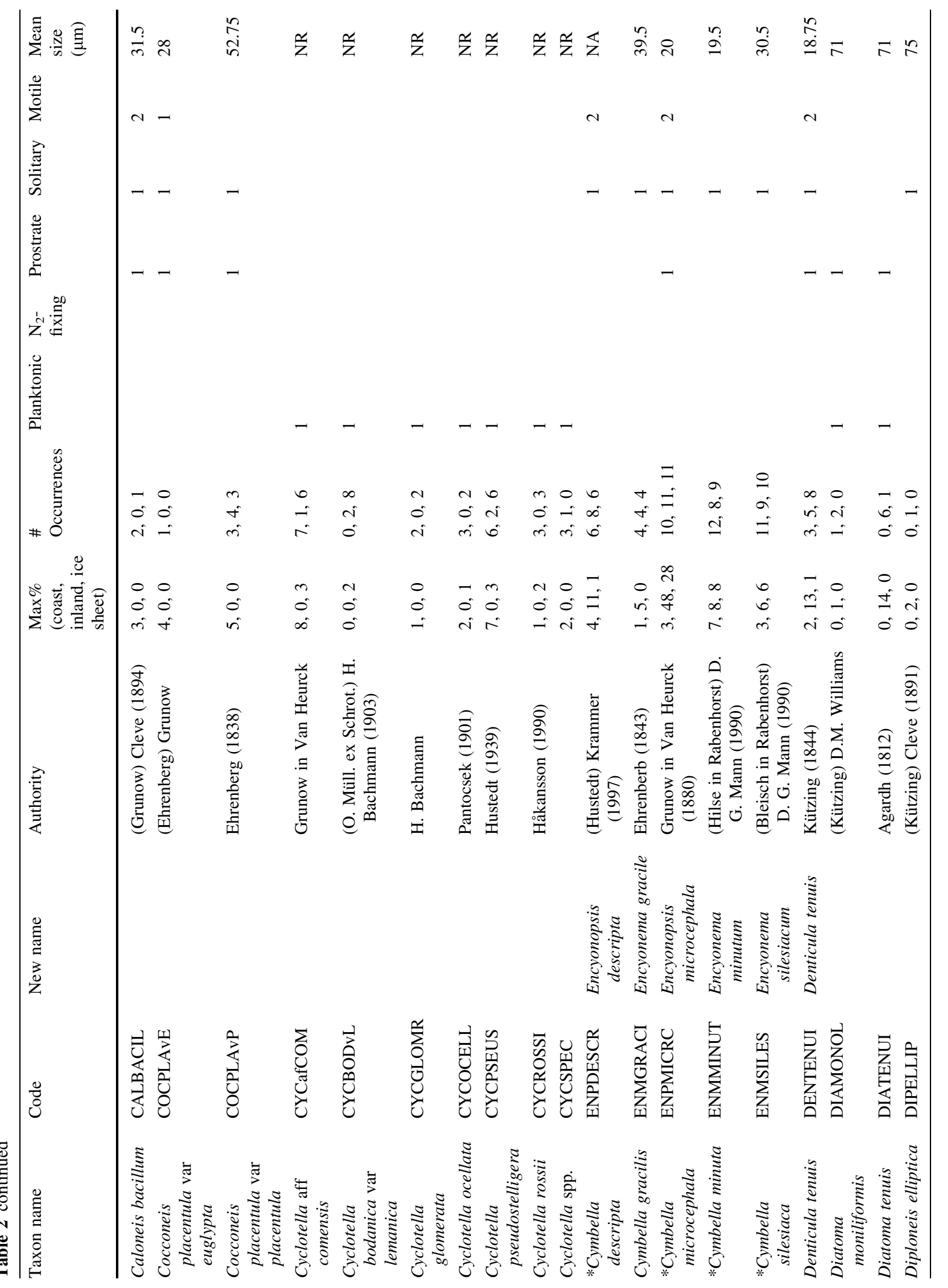




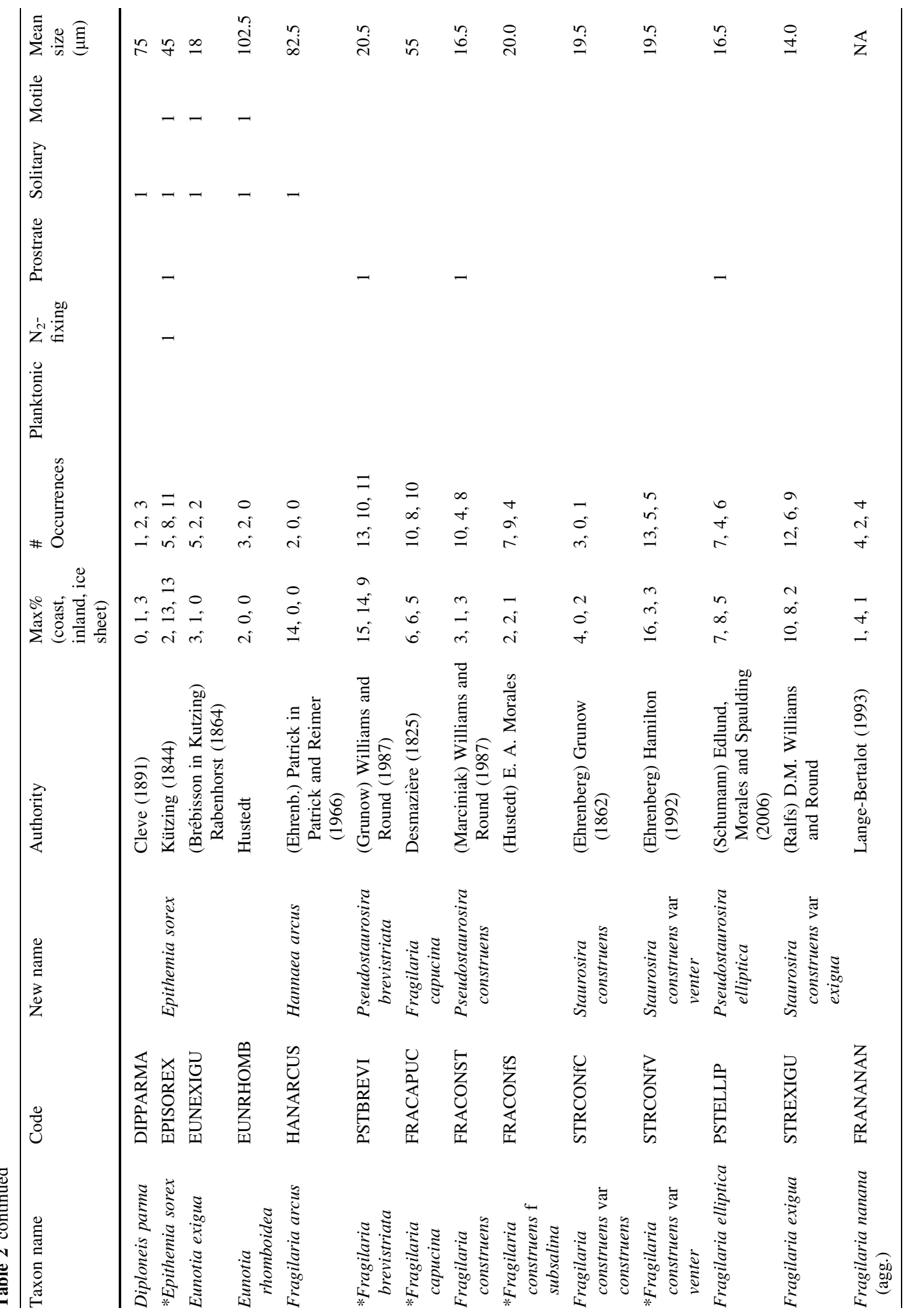




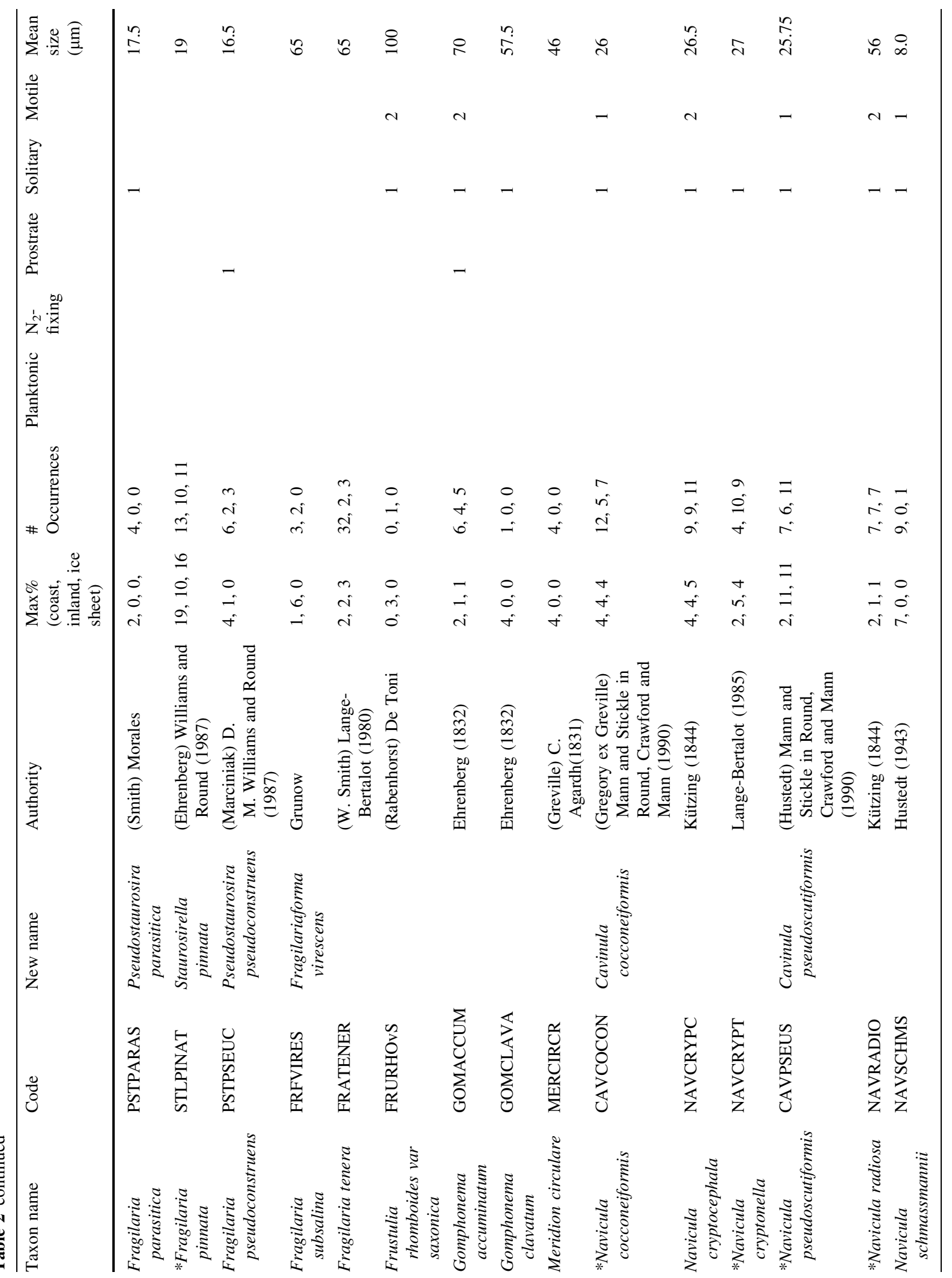




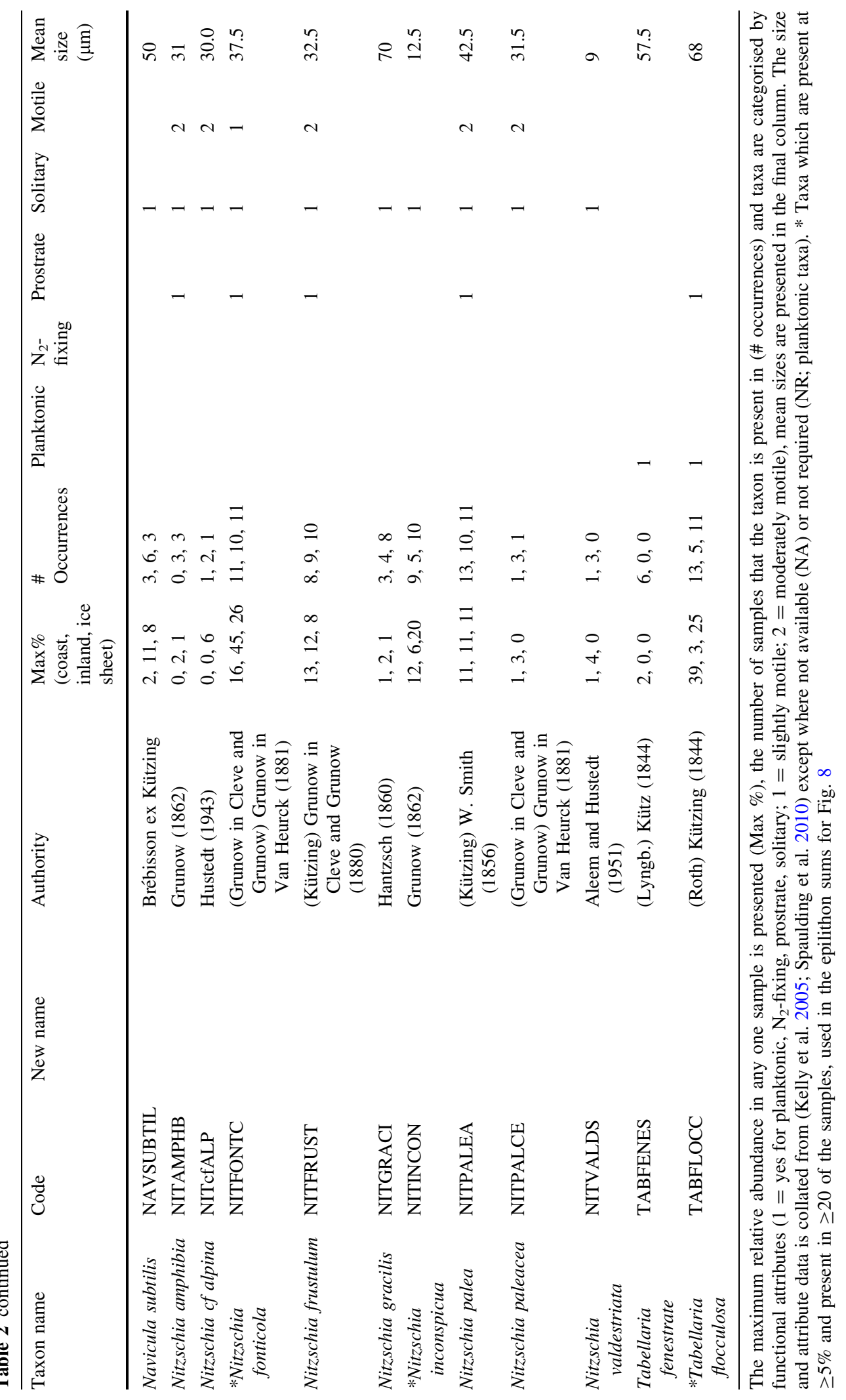


diatoms that are classified as slightly motile). Diatom sizes were also estimated by calculating the mean of the size ranges given in Kelly et al. (2005), or other sources such as Krammer and Lange-Bertalot (19861991) when necessary. This information was summarized by presenting the $\%$ of each ecological category and, for diatom size, a weighted mean of the frustule sizes in each diatom sample. When ecological information was unavailable for taxa (see Table 2), they were excluded from the integrated sums.

Epilithic diatoms in lake sediments

In three lakes (one from each region) for which HONkajak sediment cores had been sampled from the deepest part of the lake basins, we compared the relative abundance of diatoms in the uppermost $0.5 \mathrm{~cm}$ of sediment with the epilithic samples from the same lake to determine potential representation of epilithon in lake sediments. The lakes selected for this analysis were, as far as possible, similar in size and depth and included AT6 (coast), SS1381 (inland) and SS904 (ice sheet margin). For this analysis due to taxonomic difficulties Cyclotella stelligera, Cyclotella pseudostelligera and Cyclotella stelligeroides were grouped as 'Cyclotella stelligera complex'. We then used data from previously published Holocene diatom sequences in this region to test the application of the epilithic diatoms as palaeoenvironmental indicators (Law et al. 2015). Detailed site descriptions, information on the coring and construction of the sediment chronologies are given in Anderson et al. (2012) whereas information on the diatom preparation techniques are given in Law et al. (2015). To assist in the interpretation of the Lake SS8 record, sedimentary concentrations of myxoxanthophyll, a carotenoid from cyanobacteria are also presented. Pigment analysis methods followed those in McGowan et al. (2012) as outlined in Liversidge (2012).

\section{Results}

There was a pronounced difference in chemical composition of lake groups from each area (Table 1; Fig. 2). Coastal lakes had lower major ion concentrations $\left(\mathrm{K}^{+}, \mathrm{Na}^{+}, \mathrm{Mg}^{2+}, \mathrm{Ca}^{2+}, \mathrm{Cl}^{-}\right)$and lower total alkalinity, but higher concentrations of nitrate-nitrogen, silicate and sulphate ions. Inland lakes had higher concentrations of major ions, total nitrogen, ammonium and non-particulate organic carbon (NPOC) and were more diverse in terms of chemical composition than lakes from other areas. Lakes close to the ice sheet were chemically intermediate, but had more in common with the coastal than the inland sites.

Of the 185 epilithic diatom taxa from 27 genera that were identified, 75 had a relative abundance of $>2 \%$ (Table 2). In Spring 2011 the most abundant diatoms in the coastal lakes were Pseudostaurosira brevistriata, Rossithidium pusillum, Staurosirella pinnata and Tabellaria flocculosa (Table 2; Fig. 3a). Encyonopsis microcephala dominated the inland lakes with $D i$ atoma tenuis, Denticula tenuis and Nitzschia fonticola also common. At the ice sheet, E. microcephala and $S$. pinnata were co-dominant with Epithemia sorex, $N$. fonticola, Nitzschia inconspicua, Nitzschia palea and T. flocculosa, being common. The most abundant diatom in lakes at the coast during Summer 2010 was $T$. flocculosa with $R$. pusillum, Staurosira construens var. venter, S. pinnata and $N$. fonticola also being abundant (Table 2; Fig. 3b). At inland sites E. microcephala was dominant, with Encyonopsis descripta, N. fonticola, Navicula subtilis and P. brevistriata, being abundant in some sites. Summer samples from ice sheet margin lakes were dominated by E. microcephala with E. sorex, N. fonticola, S. pinnata and $T$. flocculosa being locally abundant. Across all sites the most widespread and abundant diatoms were $E$. microcephala, N. fonticola and S. pinnata (Table 2).

Diatom assemblages were most closely and significantly correlated with nutrient variables in the spring (Fig. 3a). Elevated concentrations of total nitrogen, total phosphorus, ammonium and major ions $\left(\mathrm{Ca}^{2+}\right.$, $\left.\mathrm{Mg}^{2+}\right)$ were positively correlated with axis 1 $(\lambda=0.391)$ and associated with inland lake diatom assemblages (Denticula tenuis, E. microcephala). Coastal lakes were negatively correlated with axis 1 , had elevated concentrations of nitrate and sulphate ions and assemblages where P. brevistriata, Rossithidium linearis, R. pusillum and T. flocculosa were common. Ice sheet lakes were intermediate between the two other areas, but had relatively higher proportions of E. sorex and $N$. inconspicua. CCA showed that major ions were the most significant correlates with summer epilithon (Fig. 3b). Alkalinity and major ions $\left(\mathrm{Ca}^{2+}, \mathrm{Mg}^{2+}, \mathrm{Na}^{+}\right)$were positively correlated with axis $1(\lambda=0.4171)$ and with the inland lake diatoms, predominantly E. microcephala. Silicate and sulphate 


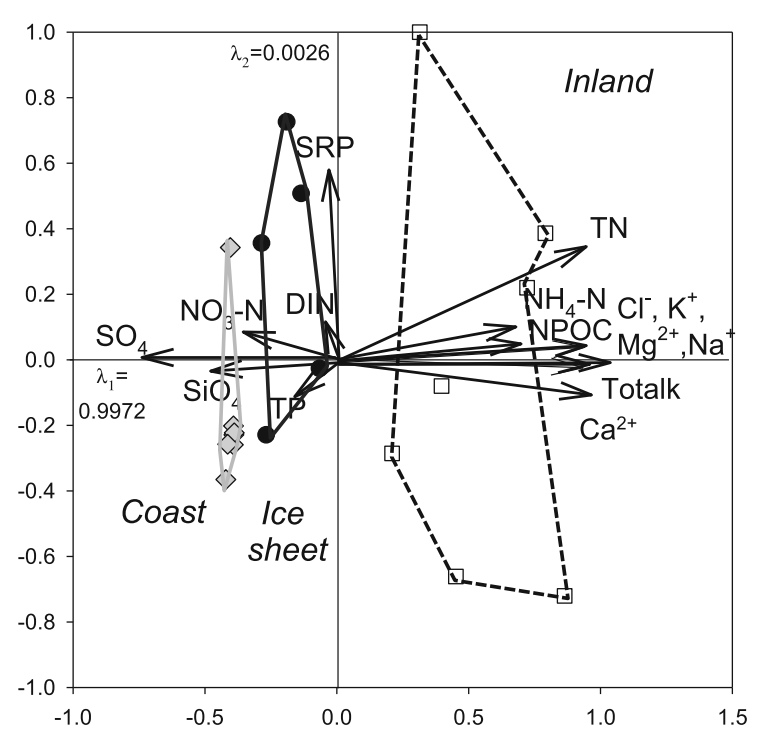

Fig. 2 PCA of mean water chemistry of study lakes. Mean values were calculated from sampling during July-August 2010, April 2011 and May-June 2011. Samples from the coast are shown in grey diamonds, from the ice sheet in black circles and from inland area in white squares, with the lines encapsulating the samples

ions were more abundant in the coastal lakes, negatively correlated with axis 1 and associated with a greater variety of diatoms (Brachysira brebissonii, $R$. pusillum, Staurosira construens var exigua, S. pinnata and $T$. flocculosa). Ice sheet lakes were intermediate along this axis 1 gradient. Water chemistry variables were highly spatially organised (Fig. 3), but variance partitioning analysis (VPA) using the partial CCA indicated that environmental variables uniquely accounted for 52.2 and $54.6 \%$ of the variance in spring and summer respectively, whilst space + environment accounted for 39.2 and $25.2 \%$ of variance. Spatial factors uniquely accounted for 8.6 and $20.3 \%$ of variance in the spring and summer periods. Thus, environment and (environment + space) accounted for more variance overall during the spring than the summer.

Epilithic diatom assemblages were generally more diverse and had greater numbers of taxa during the spring than the summer (Fig. 4a). Diatom assemblage richness and diversity was higher in the coastal lakes during Spring 2011, but not significantly so. During Summer 2010, diatom assemblage richness and diversity was significantly lower in the inland lakes relative to coastal and ice sheet lakes (Fig. 4b). Inland lakes also showed a more pronounced decline in richness and diversity in the summer relative to the spring, whereas the decline in the coastal lakes was more subtle and it increased slightly in the ice sheet lakes.

When categorised by functional attributes, assemblage characteristics were more distinctive in each lake region during the summer (more significant differences among lake regions) than the spring (Fig. 5). Proportionally more planktonic diatoms were found on the rock surfaces of coastal lakes. During the summer, planktonic diatoms were absent from rock scrapes of almost all inland sites. The distribution of $\mathrm{N}_{2}$-fixing Epithemia sorex was distinctive, with low relative abundance or absence in the coastal lakes, and significantly higher proportions in most ice sheet margin lakes and some inland sites, particularly during the summer. There was a less distinctive pattern of prostrate diatoms, but generally lower contributions of this diatom type in the coastal lakes. Solitary diatoms were significantly less abundant in coastal lakes than other areas. The pattern of motile diatoms changed seasonally; inland sites having the lowest proportions of motile diatoms in the spring, but highest during the summer. Mean diatom frustule length in the coastal lakes was generally greater than in the other areas with the differences becoming more pronounced during the summer.

Comparisons of aggregated diatom genera across seasons and regions showed a variety of patterns (Fig. 6). There were lower relative abundances of Cocconeis, Diatoma, Fragilaria and Gomphonema spp. in summer relative to the spring, but all of these genera were present in low relative abundances in the assemblage $(<10 \%)$. Other seasonal responses differed among study areas; for example Brachysira spp. increased between spring and summer in coastal sites, but declined in the inland and ice sheet sites and the converse was true for Pseudostaurosira spp. Certain genera changed most clearly along the spatial transect with indistinct seasonal trends. Epithemia, Navicula and Nitzschia spp. increased in abundance from the coast- inland- ice sheet margin, whereas the Achnanthes group, Hannaea, Staurosira and Tabellaria spp. were highest in the coastal sites, and inland the Cymbella group were significantly higher and Staurosirella were lower. 
(a) Spring 2011
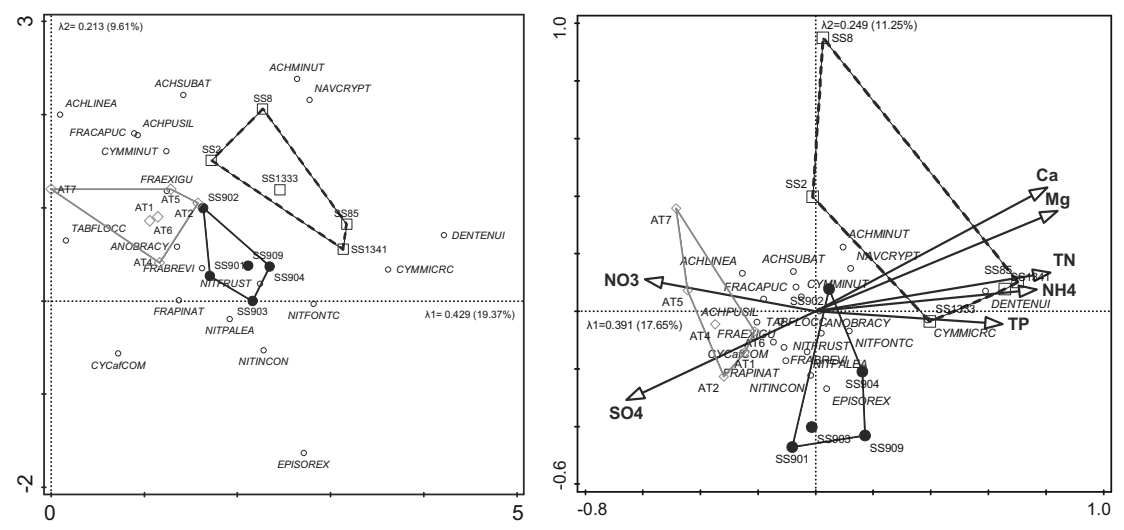

(b) Summer 2010
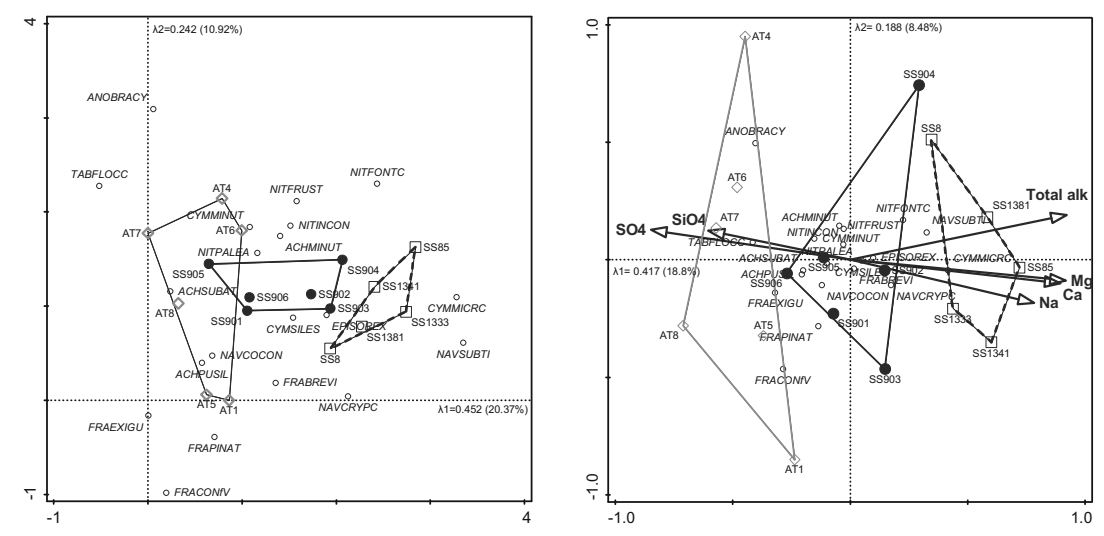
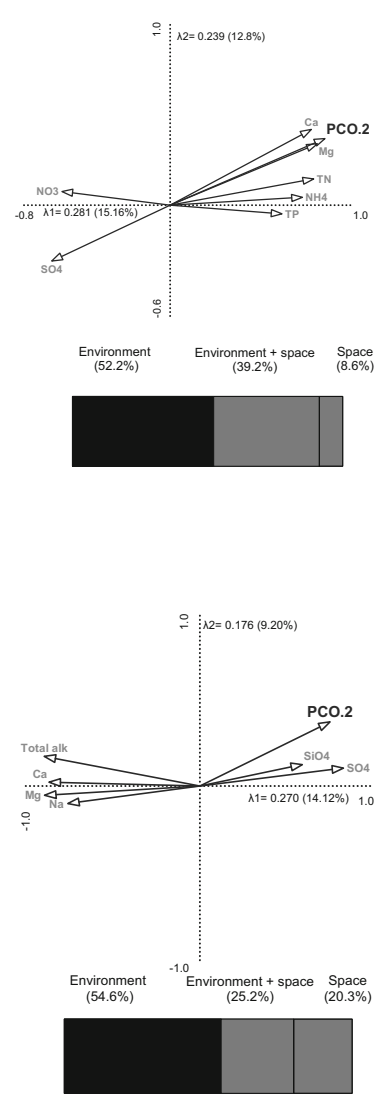

Fig. 3 DCA (left panel) of epilithic diatom assemblages (grouped by lake region), CCA (middle panel) showing relationships with limnological parameters and partial CCA (right panel) of the same environmental variables with space (PCO2) as a covariable, which was used to partition variance

Epilithon- surface sediment comparisons

Diatoms detected in the epilithon samples comprised between 15 and $40 \%$ of the taxa within the deep-water sedimentary diatom assemblage of the three lakes. While many of the common taxa were preserved in the surface sediments, several were absent (Fig. 7). In Lake AT6 of the 67 diatom taxa in the sediments, 27 were potentially from the epilithon, with a further three being found on rocks, but likely originating from the plankton (Aulacoseira alpigena, C. pseudostelligera and C. rossiilocellata complex) (Fig. 7a). This amounted to $41 \%$ of the relative abundance of diatoms in sediments from lake AT6 being epilithic taxa (excluding the probable planktonic ones). The main "non-epilithic" diatoms (as defined by our rock among environment, environment + space and space categories (shown in the bar chart) as sampled in a Spring 2011 and b Summer 2010. The diagram display is restricted to the 20 diatom taxa with the largest weight on the analysis as determined in CANOCO 5

scrapes) in sediments of this lake included C. stelligera complex, Fragilaria fasiculata, Fragilariaforma virescens, Karayevia suchlandtii and Karayevia laterostrata. Common ( $>3 \%$ ) epilithic taxa not/underrepresented in the sediment were $T$. flocculosa (12-20\% in rock assemblages), N. frustulum (1-13\%), N. inconspicua (0-12\%), B. brebissonii (6-8\%), E. minutum (5-7\%) and R. linearis (4-5\%). In the inland lake SS1381, 12 out of 29 taxa were epilithic, representing a relative abundance of $25 \%$ (Fig. 7b). In this lake, the majority of the sedimentary diatoms were planktonic taxa with $C$. bodanica var. lemanica comprising $60 \%$ of the assemblage and Achnanthidium minutissimum also being abundant. The most abundant epilithic species not recorded in sediments included $P$ brevistriata (3-39\% of the rock 
(a) Spring
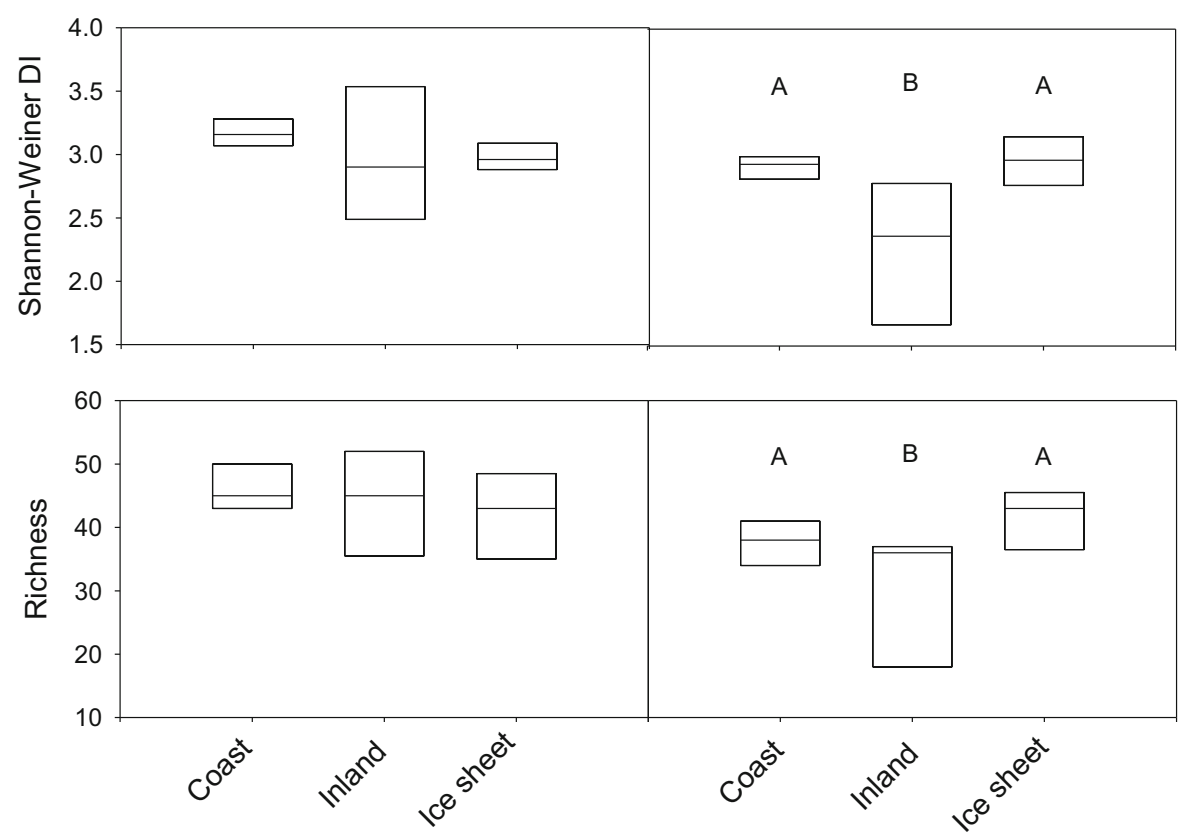

Fig. 4 Box plots showing diversity as measured by the Shannon-Weiner Diversity Index (top panel) and richness (lower panel) of epilithic diatom taxa sampled during a Spring 2011 and b Summer 2010. Significant differences $(p<0.05)$

assemblage), Psammothidium subatomoides (1-10\%), P. elliptica (3-8\%), Nitzschia palea (2-10\%), N. frustulum (1-5\%), Cocconeis placentua var. placentula (0.5-5\%), Fragilaria nanana (0-4\%), Cavinula pseudoscutiformis (0-4\%) and T. flocculosa (0-4\%). Out of 33 taxa in ice sheet lake SS904 sediments, five were recorded on rocks with a further one $(C$. bodanica var. lemanica) probably deriving originally from the plankton (Fig. 7c), making up a relative abundance of $10 \%$ of the assemblage (excluding possible plankton-derived taxa). Abundant diatoms in the sediments that were not detected in the epilithon scrapes were Pinnularia interrupta, Sellaphora laevissima, S. pinnata (although present in the epilithon of other lakes; Table 2), Amphora libyca, Navicula digitulus and the planktonic C. bodanica var. lemanica and $C$. rossii. Common epilithon diatoms not detected in the sediments included a range of Nitzschia species (N. fonticola (13-26\% of rock assemblages), $N$. inconspicua (7-8\%), N. frustulia (4-7\%) N. cf. alpina (0-6\%), N. palea (4-6\%)), E. microcephala (13-20\%), P. brevistriata (1-7\%), Navicula subtilis (0-8\%) and $R$. pusillum (4-6\%). (b) Summer

between lake regions from ANOVA and Tukey's Least Significant Difference tests are indicated by different letters (A versus $B)$

\section{Discussion}

The pronounced gradients in water chemistry identified in this study have been demonstrated in previous surveys around Kangerlussuaq, showing that lakes located inland are more enriched in major ions, nutrients and non-particulate organic carbon (NPOC) (Anderson et al. 2001; Anderson and Stedmon 2007). These patterns are largely driven by local climate where low precipitation: evaporation ratios in the inland and ice sheet marginal areas, together with aerial deposition of dust from the glacial sandur plains have led to the concentration of salts and dissolved organic carbon (DOC), low hydrological flushing rates and strong recycling of nutrients (total $\mathrm{N}$ and $\mathrm{P}$ ) (McGowan et al. 2003; Anderson et al. 2008). This dependence on inlake nutrient recycling leads to the divergence in chemical characteristics across the region and so inland lakes are more chemically diverse than lakes in other areas. In contrast the coastal area has ca. three-times greater winter snowpack depth leading to increased snowmelt and, because of active hydrological inputs, coastal lakes have much higher flushing rates (Curtis 


\section{Spring 2011}
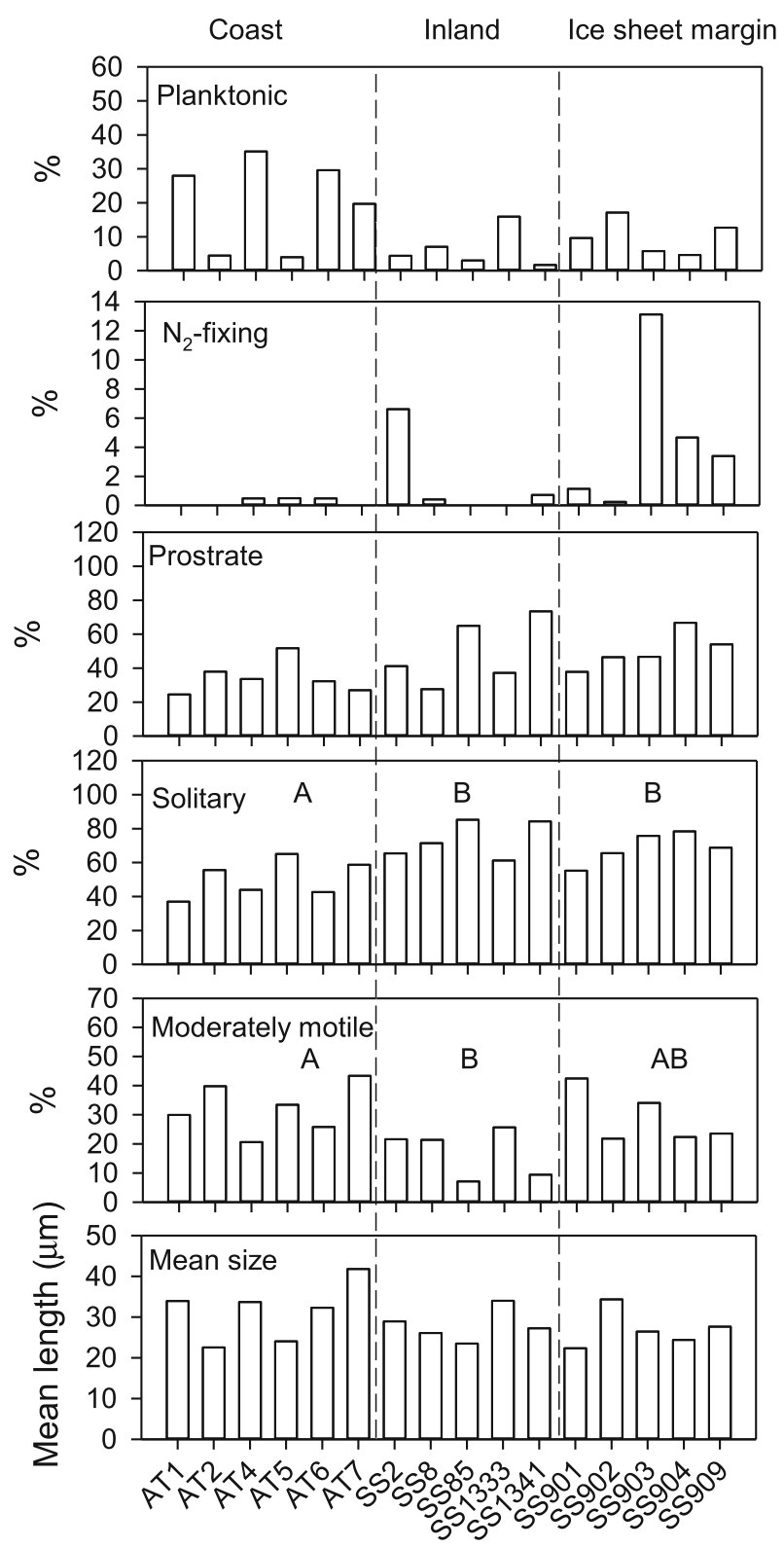

Fig. 5 Relative abundance of diatom growth forms in the study lakes in Spring 2011 and Summer 2010. Lakes are ordered by study area across the region of southwest Greenland (coastinland-ice sheet margin) with each area separated by dashed

et al., unpublished). The consequence is more dilute and slightly acidic waters, but higher concentrations of reactive $\mathrm{N}$ (as nitrate) and sulphate, which is predominantly delivered in the spring from atmospheric deposits accumulated in over-winter snow pack (Hogan et al. 2014; Whiteford et al. 2016). Most nitrogen in

\section{Summer 2010}

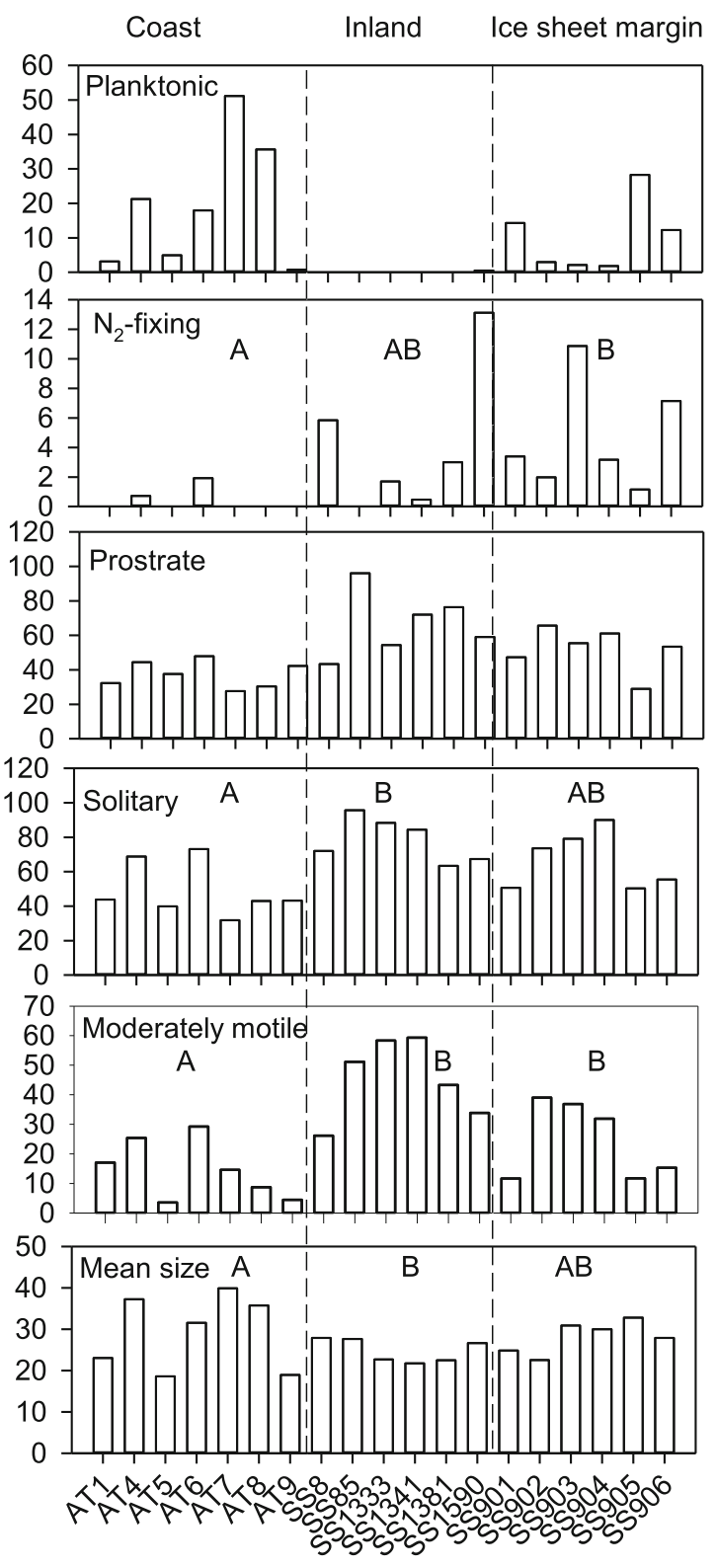

horizontal lines. Significant differences $(p<0.05)$ between lake regions from ANOVA and Tukey's Least Significant Difference tests are indicated by different letters ( $A$ versus $B$ )

inland lakes is present as ammonium and total $\mathrm{N}$ (including organically-bound) forms, consistent with a strong reliance on in-lake recycling and retention of nitrogen with the oxygen-depleted bottom waters in many of the inland lakes where ammonium is replete, deriving from the decomposition of organic matter. 


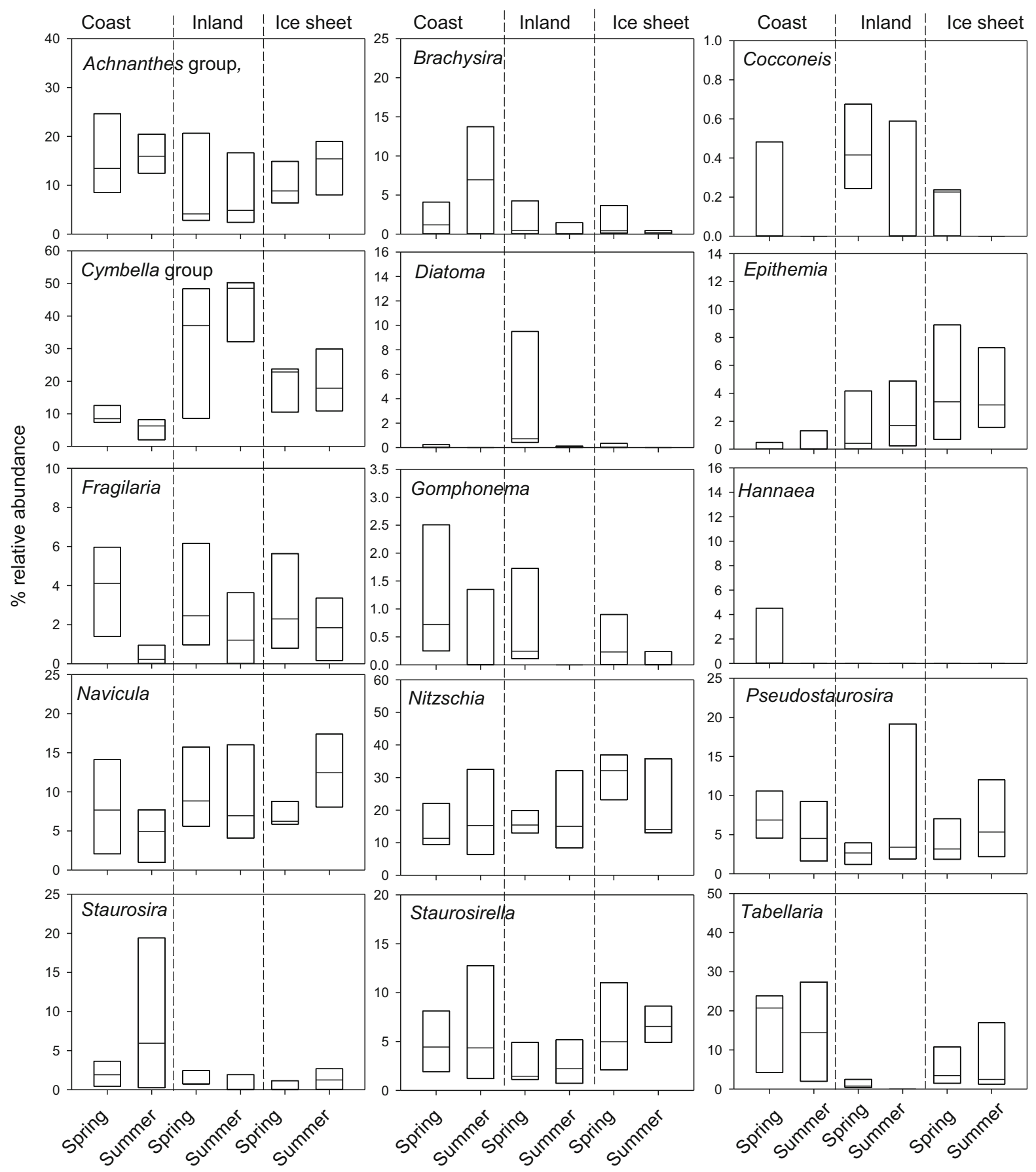

Fig. 6 Epilithic diatom variability among study areas (coastinland-ice sheet margin) and sampling occasion (spring, summer). Diatoms are summed by genera or families including

Higher silicate concentrations in coastal lakes are linked with the more intense weathering of the gneiss bedrock in the region and efficient delivery to lakes due to the wetter conditions (Anderson et al. 2012). The ice sheet the Achnanthes group (Achnanthes, Achnanthidium, Platessa, Karayevia, Psammothidium, Rossitihidium, Planothidium spp.) and Cymbella group (Encyonema, Encyonopis)

margin lakes are intermediate in terms of water chemistry; there is limited precipitation but cooler conditions which slow down evaporation rates limiting the evapo-concentration of major ions and DOC 

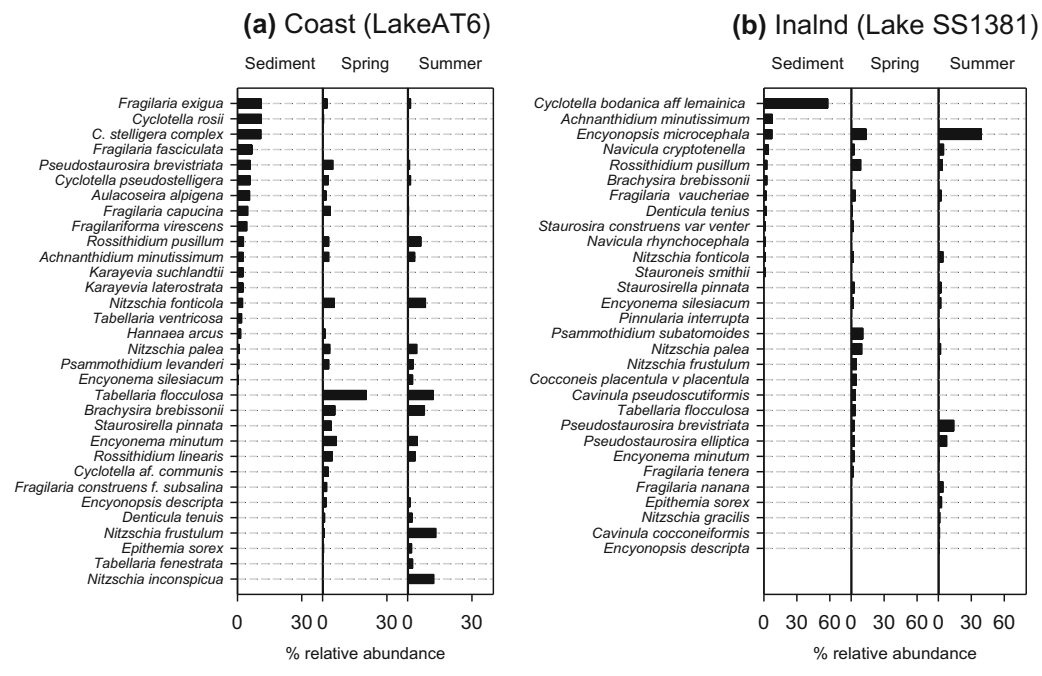

(c) Ice sheet (Lake SS904)

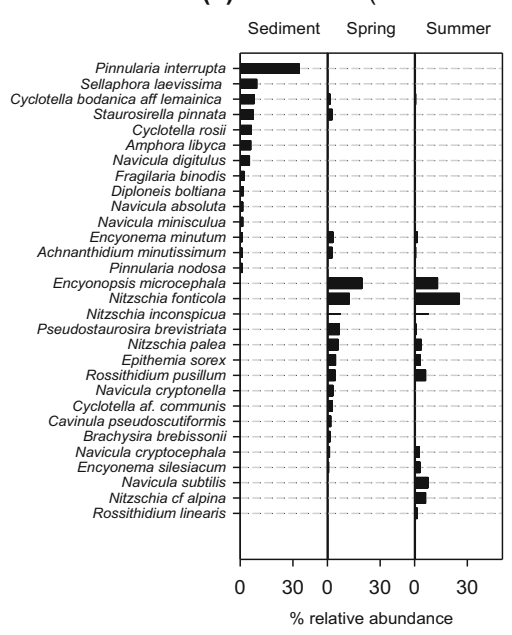

Fig. 7 Comparisons of diatom assemblages from profundal surface sediments and epilithon scrapes of study lakes a AT6 (coast) b SS1381 (inland) lakes and c SS904 (ice sheet margin). Sediment cores were extracted from the deepest part of each

(Anderson and Stedmon 2007) but greater inputs of phosphorus from aeolian dust.

Previous training set studies of surface sediment diatom and chironomid assemblages show that chemical differences within this lake district correlate with changes in biota, although they included the chemically-distinct "saline" lakes which were excluded from this study (Brodersen and Anderson 2002; Ryves et al. 2002). See Pla and Anderson (2005) for comparisons of saline and non-saline chrysophyte cyst assemblages. Here, differences among littoral epilithic diatom assemblages in the three areas (coast, inland, ice sheet margin) confirmed that they were responding to the different lake conditions, even along a narrower freshwater chemistry gradient; variance from CCA axes 1 and 2 explained about $25 \%$ in Ryves et al. (2002) compared with values in this study of $29 \%$ in the spring and $27 \%$ in the summer. The pCCA (Fig. 3) analysis identified that epilithic diatoms were most closely correlated with nutrients in the spring and with major ions in the summer (when nutrient concentrations were lower), because nutrients are rapidly depleted from these lakes after ice-off (Whiteford et al. 2016). Such observations are commensurate with the idea that nutrients in snowmelt and meltwater delivery is an important determinant of epilithic diatom assemblages (Catalan et al. 2002). Nevertheless, silicate was positively correlated with diatoms at lake for comparison to epilithon assemblages sampled during Spring 2011 and Summer 2010. The most abundant diatoms from each respective sample are selected

the coast during the summer, suggesting that the greater availability of this nutrient in these more rapidly flushed lakes may be important in structuring the diatom assemblages, resulting in greater abundance of heavily silicified diatoms (Tabellaria, Staurosira and Staurosirella). The partial CCA and VPA demonstrated that more than half of the variance explained by the CCA could be attributed solely to environmental factors, confirming that diatoms are robust indicators of water chemistry variables. Additionally however, just under half of the variance was correlated with spatial or (environmental + spatial) factors, (i.e. chemical and other factors co-varied with lake region). Thus, the relationships between environmental variables and diatoms that we identified might be partly be explained by un/measured variables which also co-varied with location (for example fish abundance which is lower in the hydologicallyisolated inland/ice sheet lakes) (Juggins 2013). The analysis further highlights how sampling during different seasons can influence correlations, with implications for palaeoecological interpretations.

Functional attributes of epilithic diatoms

"Pioneer" diatom taxa which are present during the early spring period could provide information about phenology, and therefore have potential as 
palaeoclimate indicators. Unfortunately only a few diatoms showed consistently higher abundances in the spring (Gomphonema, Cocconeis, Diatoma and Fragilaria species), and they comprised low proportions of the total assemblages. The presence of Gomphonema is consistent with observations that it is a successful colonising species in resource replete environments (McCormick and Stevenson 1991), growing shortly after snowmelt when reactive nitrogen is abundant (Whiteford et al. 2016). Hannaea arcus is strongly associated with the spring period, but only in some of the coastal lakes. This diatom has previously been used as an indicator of riverine inputs (Douglas et al. 1996), demonstrating that surface inflows into lakes at the coast are most active after the spring snowmelt period. Overall though, spring assemblages included a diverse mix of adnate (Achnanthes, Cocconeis), motile (Nitzschia, Navicula, Brachysira, Cymbella), stalked (Gomphonema) and unattached/loosely attached colonial taxa ( $\mathrm{Ta}$ bellaria, Pseudostaurosira, Staurosira, Staurosirella) alongside planktonic taxa (Diatoma, Cyclotella) which had settled onto rocks from the lake seston. The spring sampling took place within a few weeks (inland sites), or days following ice-off (coastal, ice sheet margin lakes) and suggests that biofilm and diatom assemblage succession to a mature three-dimensional community takes place over short timescales of days-weeks (Peterson 1996) and may contain 'memory' of overwintering taxa from the previous growth season (Quesada et al. 2008). Identification of early colonizers in these lakes might have been better detected by sampling lakes prior to ice-off when only moating had occurred. This only happened at some of the sites in the coastal area where remnants of ice remained, and is practically difficult to achieve when access to lakes is restricted and ice-off dates are difficult to predict.

Comparison of the spring and summer epilithon samples suggests that successional trajectories differed in each lake region, and that seasonal differences were most pronounced in the inland sites. Species diversity and richness declined and motile species (mostly Encyonopsis microcephala, Nitzschia and Navicula species) became more dominant during the summer in the inland and ice sheet lakes. E. microcephala is a common component in biofilms in the later stages of diatom succession (Stevenson et al. 1991; Barbiero 2000). We infer that low silicate concentrations during the summer and the availability of nitrogen and phosphorus in organically bound forms at the inland sites led to the development of more complex biofilms with proportionally more non-siliceous algae, as confirmed by previous periphyton experiments (Hogan et al. 2014). The greater availability of dissolved organic matter (NPOC) in the inland sites implies more intense heterotrophic microbial processing. Complex biofilms are well suited to motile diatom taxa because they can move up and down for light harvesting, and some Nitzschia species can secrete extracellular enzymes to decompose organic compounds for heterotrophic nutrition (Tanaka and Ohwada 1988; Tuchman et al. 2006). It is likely that they compete very effectively in highly organic biofilms and in lakes with abundant organic $\mathrm{C}$ because exopolymers are also important for diatom motility (Smith and Underwood 1998). In line with this observation, contamination of an Arctic lake with organic sewage was shown to increase the relative abundance of Navicula and Nitzschia taxa (Michelutti et al. 2007b). It is noteworthy that the replacement of Fragilaria/fragilarioid taxa with Nitzschia has been observed in several Arctic lakes in recent decades (Antoniades et al. 2005b; Keatley et al. 2006), raising the question that such shifts may indicate organic enrichment of lakes, which could be associated with important Arctic processes such as permafrost melt (Pokrovsky et al. 2011) and 'Arctic greening' (McGowan et al. 2016).

As well as more motile species, more prostrate diatom taxa were also observed in the inland lakes later in the growth season. Prostrate forms are suited to growth as epiphytes on algal filaments and so may be an adaptation to growth in complex microbial mats (McCormick and Stevenson 1991). Grazing pressure might also be a structuring force for diatoms in the inland lakes because most lack fish due to hydrological isolation. The absence of top predators, longer and warmer ice-free seasons and the alkaline conditions which are more suitable for calcareous organisms such as molluscs should make these lakes especially suited to rich and diverse invertebrate grazer communities (Bennike 2000; Brodersen and Anderson 2002; Reuss et al. 2014). Thus, adnate growth forms may be an adaptation for grazer avoidance (Jones et al. 2000). The other very marked seasonal pattern in the inland lakes is the absence of 
planktonic diatoms in the summer period, associated with epilimnetic depletion of silicate (and other nutrients). For example, Diatoma tenuis is common in the plankton of meromictic saline lakes in this region (Willemse et al. 2004) and thus is categorized as a halophilic diatom in the training set of Ryves et al. (2002). Its presence in these lakes (conductivity $<605 \mu \mathrm{S} \mathrm{cm}^{-1}$ ) demonstrates that it is most likely not driven by salinity, but rather an ability to grow rapidly after ice out when nutrients are available until silica is depleted (Morabito et al. 2003). Overall, the hydrological isolation and warm summer conditions of the inland lakes appear to have multiple influences on epilithic diatoms by limiting external nutrient delivery (especially silicate), increasing the dependence on in-lake cycling of organically-bound nutrients and modification of food web structure through the absence of top predators.

Some diatoms were apparently influenced more by the overall conditions within lake regions than by seasonal changes. For example, nitrogen-fixing diatoms, represented solely by E. sorex in this dataset, were most abundant in ice sheet lakes and common in the inland sites. E. sorex is known to host endosymbiotic $\mathrm{N}_{2}$-fixing cyanobacteria (DeYoe et al. 1992) and its presence is consistent with our observations that delivery of reactive nitrogen in this region is two times lower than at the coast (Curtis et al. unpublished). Bioassay experiments confirm that periphyton growth in the summer is nitrogenlimited in the ice sheet lakes and limited by nitrogen and phosphorus inland, explained by the enhanced supply of $\mathrm{P}$ to ice sheet lakes in dust which blows from fluvioglacial deposits from the ice sheet (Hogan et al. 2014). Highly silicified Tabellaria, Staurosira and Staurosirella were abundant in both seasons in the coastal lakes. Tabellaria flocculosa is often associated with dilute and acidic waters, and "acid pulses" in spring snowmelt in upland sites (Knudson and Kipling 1957; Cameron et al. 1999; Štefková 2006). However, our analyses indicate that perennial rivers flowing into the coastal sites (several served by snow banks higher in the catchment) throughout the summer likely maintained optimal conditions for growth of these taxa. The close correlation with sulphate ions in the CCA suggests that $T$. flocculosa is strongly responsive to water chemistry and it is common in the epilithon of acidified and subarctic lakes (Albert et al. 2009).
Representation of littoral epilithic diatoms in sediments

Sampling of individual habitats can provide information about habitat preferences, but many benthic diatoms grow on multiple substrate types (Lim et al. 2001b). Therefore, although this study has identified the diatoms which may grow on rock surfaces at the lake margins, it has not demonstrated habitat specificity because other benthic habitats (including deeper epilithon) were not sampled (Cantonati et al. 2009). The discussion below identifies such diatoms as shallow water epilithon, but acknowledges the caveat that other habitats were not sampled. Epilithic diatoms made up a rather small proportion of the lake sedimentary diatom assemblages (between 10 and $41 \%$ ). Lake bathymetry is an important influence on the proportions of epilithic diatoms in sediments because the subfossil diatoms derive from plankton and a variety of benthic habitats (Stone and Fritz 2006; Anderson and Battarbee 1994). Photic zone depth is similar across this lake district (mean and standard deviation of $17 \pm 0.5 \mathrm{~m}$ at the coast, $15.2 \pm 0.8 \mathrm{~m}$ inland and $18.6 \pm 0.9 \mathrm{~m}$ at the ice sheet) (Whiteford et al. 2016) and extends to the bottom of most lakes (SS904 maximum depth $11.4 \mathrm{~m}$; SS1381, $18.5 \mathrm{~m}$; AT6 $23 \mathrm{~m}$ ) indicating that most of the benthic region in each lake received sufficient light during the icefree season to support photosynthetic communities. Thus non-planktonic diatoms usually comprise around $50 \%$ of the total sedimentary diatom assemblage in many lakes in this region (Ryves et al. 2002) and benthic production is important in these lakes. The very low representation of epilithic diatoms in the ice sheet lake SS904 (10\%) may be explained by the greater proportion of other benthic algae including Pinnularia interrupta and Sellaphora leavissima. Many Pinnularia species are epiphytic on mosses in arctic lakes (Michelutti et al. 2006) and S. leavissima is known to be epipelic, suggesting that SS904 may have well developed aquatic plant coverage.

Taphonomy of sedimentary diatom assemblages might be influenced by the dissolution of frustules and those from nearshore environments are particularly prone to resuspension from turbulence and breakage, making them susceptible to dissolution (Ryves et al. 2006). In contrast, planktonic diatoms may be quite rapidly deposited into sediments, sometimes assisted by sinking in zooplankton faecal pellets (Cameron 
1995). Such differences in transport efficiency would make littoral epilithic diatoms more susceptible to modification by the chemical conditions in lakes, and the lower silicate concentrations and higher salt concentrations/alkalinities in the inland and ice sheet lakes may have increased the dissolution of frustules (Ryves et al. 2006). The low sedimentation rates, typical of Arctic lakes, also increases exposure to unfavourable chemical conditions, and thus periods of poor diatom preservation are common in sediment cores from the inland lakes (Law et al. 2015). The sediment-epilithon comparisons suggest that there is selective loss of certain taxa from the epilithic communities. In particular, Tabellaria flocculosa, common in the coastal lakes' epilithon, is underrepresented in the sediments in Lake AT6, and it is possible that this colonial and loosely attached/ unattached diatom is susceptible to washout in these lakes which are rapidly flushed. Nitzschia species are particularly under-represented in sediments of the inland/ice sheet lakes. Nitzschia are renowned for their low representation in many lake sediments, possibly associated with their lightly silicified frustules which dissolve easily (Ryves et al. 2003; Battarbee et al. 2005). The other taxon that is important in epilithon and yet poorly represented in sediments in the ice sheet lakes is Encyonopsis microcephala. It appears therefore, that solitary diatoms (Encyonopsis, Nitzschia) are especially susceptible to taphonomic processes, and their smaller surface area relative to colonial growth forms might expose them to chemical dissolution and breakage. In lakes such as these with slow sedimentation rates, the diatoms deposited in surface sediments are mixed together with existing sedimentary assemblages and so the cumulative upper sediments can differ substantially from the source assemblage (Cameron 1995). This effect is particularly pronounced if contemporary algal deposits are different from those previously deposited as may be the case in this region of Greenland which is now rapidly changing (Anderson et al. 2016).

The surface sediment comparisons of the three lakes across the lake district indicate greater abundance of epilithic diatoms in the coastal lake, and of epilithic + epipelic diatoms in the ice sheet lake, each of which lose ice at a slower rate than the inland lakes. This agrees with suggestions that lakes which undergo prolonged periods of moating should have a greater proportion of periphyton relative to plankton (Douglas and Smol 1999; Catalan et al. 2002). When lakes are moating, epilithic algae in littoral areas have access to nutrients from snowmelt, which might provide a competitive advantage over planktonic diatoms which would be comparatively constrained by light availability under ice and lack of wind mixing (Bertilsson et al. 2013). Furthermore, snowmelt is three times greater at the coast leading to a two-fold greater flux of inorganic nitrogen into the coastal lakes than the inland area (C. Curtis, unpublished), which could account for the greater proportions of littoral epilithic diatoms (Whiteford et al. 2016). The proportional contribution of littoral epilithon to overall diatom assemblages is lowest at the ice sheet lake, where epipelic diatoms are more common. We propose that the greater numbers of plant- and sediment-associated diatoms in the ice-sheet lake are instead utilizing sedimentary nutrient sources, which may derive from the mineralisation of dusts settling onto the sediment surfaces of these lakes (Anderson et al. 2016), and the lower snowmelt relative to the coastal lakes limits littoral epilithic diatoms. Whilst more evidence is required to test these hypotheses, they do highlight the diverse controls on benthos throughout one discrete area of the Arctic, and suggest that a more critical interpretation of benthic:pelagic diatom ratios in sediment cores is necessary.

Interpreting epilithic diatoms in sediment cores

Indicator epilithic taxa in Holocene sediment cores from across this region were able to provide new insights into previously published diatom records (Fig. 8). For example, the $\mathrm{N}_{2}$-fixing species Epithemia sorex dominated the diatom assemblage of Lake SS8 from the inland region during two periods ca. 8000 years BP and 6800 years BP (Fig. 8a). It should be noted that there are issues with diatom dissolution at this site, and so the heavily silicified $E$. sorex might be over-represented in the sediment assemblage due to preferential preservation (Law et al. 2015). However, elevated concentrations of the carotenoid myxoxanthophyll (from potentially $\mathrm{N}_{2}$-fixing cyanobateria) strengthen the idea that $\mathrm{N}_{2}$-fixers were dominant in the lake during this time period. Concurrent peaks in Epithemia adnata are also observed in nearby Lake SS1381, demonstrating the utility of other Epithemia species as indictors of nitrogen limitation (Fig. 8c). The earlier peak in inferred-nitrogen fixation around 
(a)

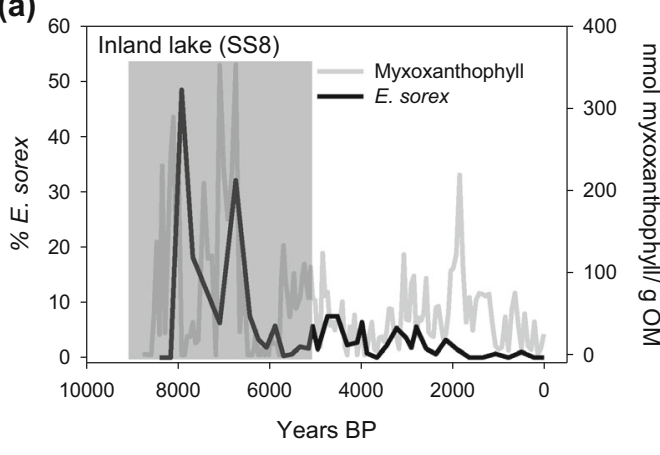

(b)

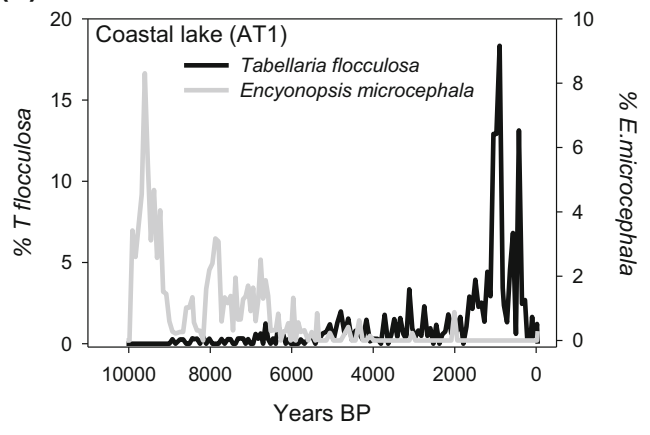

Fig. 8 a Relative abundance of Epithemia sorex in a Holocene sediment core from Lake SS8 in the inland region (black) compared with the concentration of myxoxanthophyll pigment per unit organic matter sediment (grey). A zone of poor diatom preservation is shaded grey; $\mathbf{b}$ the relative abundances of Tabellaria flocculosa (black) and Encyonopsis microcephala (grey) in a sediment core from Lake AT1 in the coastal region;

8000BP is most likely connected to conditions when soil development was rudimentary and so inputs of $\mathrm{N}$-rich DOM were limited, whereas the presence of glacially derived tills rich in $\mathrm{P}$ led to an imbalance in $\mathrm{N}: \mathrm{P}$ ratios. However, the very dry conditions during the Holocene Thermal Maximum, which increased towards 6800BP and led to a regional drawdown of terminal lake basins (McGowan et al. 2003; Aebly and Fritz 2009) was most likely very important in limiting the hydrological transfer of nitrogen from the catchment to lake basins at this time. Such nitrogen-limited conditions are common today in lakes of arid regions (Leavitt et al. 2006), and it is possible that lake level drawdown in Lake SS8 might have provided further habitat for the colonisation of epilithic E. sorex species (Law et al. 2015). Epilithic indicators in Holocene records from the coastal region also provide further evidence for ontogenetic lake development in this (c)

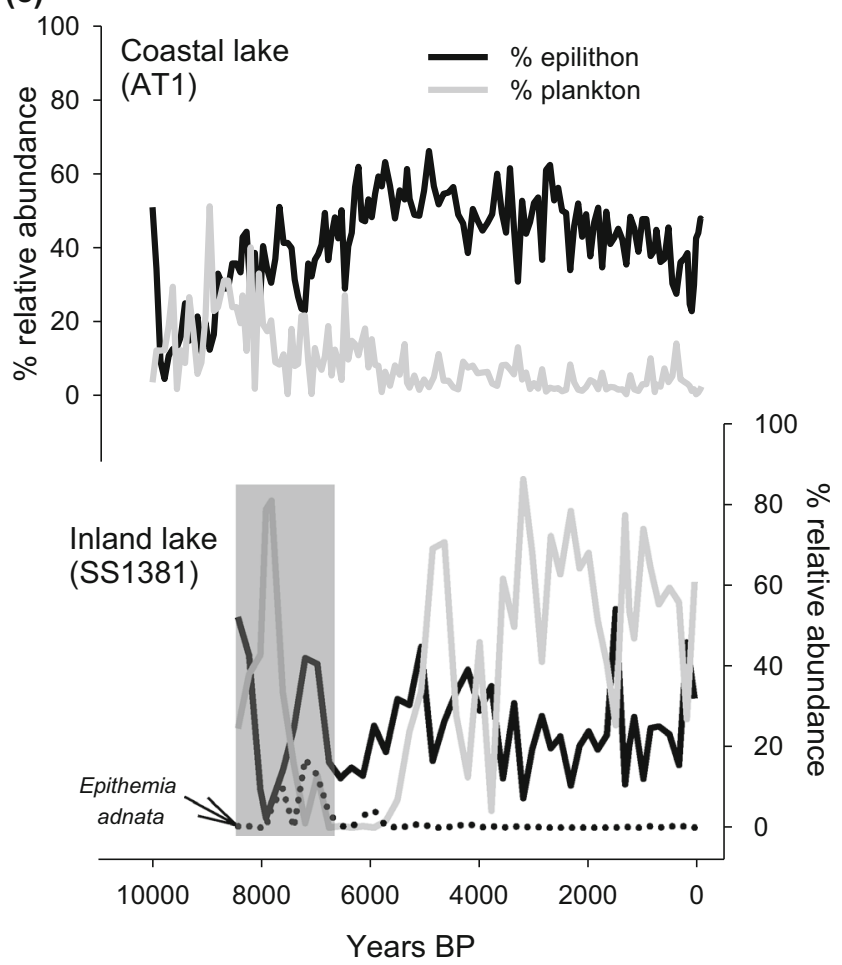

c sums of the common epilithic taxa (black line) as defined in Table 2 and planktonic taxa (open circles) in sediment cores from coastal lake AT1 and inland lake SS1381. The relative abundance of Epithemia adnata (grey line) and a zone of poor diatom preservation (grey shaded area) are also shown in Lake SS1381

region (Fig. 8b). For example, in lake AT1 Encyonopsis microcephala which strongly indicates conditions in the more alkaline and ion-rich inland/ice sheet sites is abundant in the early period of the lake development (around 9600BP). This fortifies previous interpretations of the early stages in lake ontogeny which suggests that lakes are more alkaline (Law et al. 2015), and also agrees with records of UVR-screening pigments and carotenoids (Liversidge 2012) (not shown here) which indicate that DOC and cyanobacteria were abundant in the lake, analogous to conditions in the inland lakes today. After the mid Holocene, Tabellaria flocculosa increased in AT1 to two maxima at 372-850BP, indicating long-term acidification of the site which was driven by the cooler and wetter conditions of the Neoglacial and associated with an increase in water clarity (Anderson et al. 2012; Liversidge 2012). 
We investigated sums of epilithon in sediment records through the Holocene Thermal Maximum and Neoglacial cooling periods (Anderson et al. 2012) in coastal lake AT1 and inland lake SS1381 to investigate responses to known climatic perturbations (Fig. 8c). In Lake AT1, following on from an initial period of ontogenetic change where the pioneer species $S$. pinnata was dominant, epilithon proportions increased to a maximum around ca. $6000 \mathrm{BP}$, and declined gradually during the Neoglacial cooling period. There is, therefore, no evidence of a simple link whereby cooler conditions slow down ice melt and enhance relative epilithon growth. However, evidence from a nearby cirque basin imply enhanced cryogenic processes and catchment degradation between 5800 and $4000 \mathrm{BP}$, suggesting an increase in snowpack in this area around the time of the relative epilithon expansion (6000-4000 BP) at Lake AT1 (Anderson et al. 2012). Whilst acknowledging that controls on benthic diatoms are diverse, we infer that epilithon expansion in Lake AT1 is, in part, driven by changes in precipitation and snowpack and that the wetter period between 6000-4000 BP provided habitat for littoral diatoms which benefitted from the extended moating periods (Catalan et al. 2002). The absence of long-term patterns in epilithon relative abundance in the inland lake SS1381 where conditions are more arid and hydrological inputs from the catchment are limited suggests that such a mechanism does not operate in this lake. Therefore, interpretation of longer term patterns in epilithon abundance may be best considered alongside hydrological changes in the lake catchment. In comparison with planktonic taxa which are also strongly determined by thermal stratification characteristics in lakes (Saros et al. 2016), it might be that the linkages between epilithon and lake hydrology (and therefore climate) are more straightforward, but these hypotheses require more rigorous testing.

\section{Summary}

We demonstrated strong correlations between water chemistry and littoral epilithic diatoms across this lake district in West Greenland, despite some spatial covariance. In particular, nitrate-nitrogen concentrations (which were greater at the coast in the spring) and silicate (more abundant in summer at the coast) were important determinants of diatom distributions. We identified that Epithemia species are useful indicators of nitrogen limitation via spatial surveys and longterm sedimentary sequences, and therefore, along with similar endosymbiotic taxa (Rhopalodia species) they might be used to infer long-term changes in lake nitrogen cycling. It proved difficult to identify early 'pioneer' spring taxa that could be unambiguously used as phenological indicators, although Gomphonema and Hannaea arcus were associated with spring snowmelt in some river-fed lakes at the coast. However, we identified some seasonal differences in the inland lakes where more complex biofilms developed in the summer during the longer growing season, resulting in diatom assemblages with low species richness that were small, motile and adnate. Such observations identified the potential use of Nitzschia spp and/or Encyonema microcephala as indicators of organic-rich conditions, as can occur in lakes associated with permafrost melt and catchment vegetation expansion, but preservation of these taxa in sediments is problematic. Littoral epilithic taxa have potential as palaeoecological indicators of snowmelt conditions because they are strongly influenced by nutrient delivery and chemical conditions in the spring, but interpretation of such patterns depends on the hydrological context.

Acknowledgements This work was funded by a NERC standard Grant NE/F01164X/1 to NJA, SMcG and VJJ and a Royal Geographical Society Fieldwork Apprenticeship to HG. We thank Chis Barry, Chris Curtis, Jeff Joensen, Rachael Lem, Gavin Simpson and James Whiteford for assistance in the field, and Teresa Needham for help in the laboratory, and two anonymous reviewers for their helpful comments.

Open Access This article is distributed under the terms of the Creative Commons Attribution 4.0 International License (http:// creativecommons.org/licenses/by/4.0/), which permits unrestricted use, distribution, and reproduction in any medium, provided you give appropriate credit to the original author(s) and the source, provide a link to the Creative Commons license, and indicate if changes were made.

\section{References}

Aebly FA, Fritz SC (2009) Paleohydrology of Kangerlussuaq (Søndre Strømfjord), West Greenland during the last $\sim 8000$ years. Holocene 19:91-104

Albert R-L, Korhola A, Sorvari S (2009) Analysis of factors controlling epilithic diatom community compositions in subarctic lakes of Finnish Lapland. Adv Limnol 125-151 
Anderson NJ, Battarbee RW (1994) Aquatic community persistence and variability: a palaeolimnological perspective. In: Giller PS, Hildrew AG, Raffaelli DG (eds) Aquatic ecology scale, pattern and process. Blackwell Scientific Publications, Oxford London Edinburgh Boston Melbourne Paris Berlin Vienna, pp 233-259

Anderson NJ, Stedmon CA (2007) The effect of evapoconcentration on dissolved organic carbon concentration and quality in lakes of SW Greenland. Freshw Biol 52:280-289

Anderson NJ, Harriman R, Ryves DB, Patrick ST (2001) Dominant factors controlling variability in the ionic composition of West Greenland lakes. Arct Antarct Alp Res 33:418-425

Anderson NJ, Brodersen KP, Ryves DB, McGowan S, Johanssen LS, Jeppesen E, Leng MJ (2008) Climate versus in-lake processes as controls on the development of community structure in a Low-Arctic lake (South-West Greenland). Ecosystems 11:307-324

Anderson N, Liversidge A, McGowan S, Jones M (2012) Lake and catchment response to Holocene environmental change: spatial variability along a climate gradient in southwest Greenland. J Paleolimnol 48:209-222

Anderson NJ, Saros JE, Bullard JE, Cahoon SMP, McGowan S, Bagshaw EA, Barry C, Bindler R, Burpee BT, Carrivick JL, Fowler RA, Fox D, Fritz SC, Giles M, Hamerlik L, Ingeman-Nielsen T, Law AC, Mernild SH, Northington RM, Osburn CL, Pla-Rabès S, Post E, Telling J, Stroud DA, Whiteford EJ, Yallop M, Yde JC (2016) The Arctic in the 21st century: changing biogeochemical linkages across a paraglacial landscape of Greenland. Bioscience 67:118-133

Antoniades D, Douglas MS, Smol JP (2005a) Benthic diatom autecology and inference model development from the Canadian High Arctic archipelago. J Phycol 41:30-45

Antoniades D, Douglas MS, Smol JP (2005b) Quantitative estimates of recent environmental changes in the Canadian High Arctic inferred from diatoms in lake and pond sediments. J Paleolimnol 33:349-360

Barbiero RP (2000) A multi-lake comparison of epilithic diatom communities on natural and artificial substrates. Hydrobiologia 438:157-170

Battarbee RW, Jones VJ, Flower RJ, Cameron NG, Bennion H, Carvahlo LR, Juggins S (2001) Diatoms. In: Smol JP, Birks HJB, Last WM (eds) Tracking environmental change using lake sediments. Kluwer Academic Publishers, Dordrecht, pp 155-202

Battarbee RW, Mackay A, Jewson D, Ryves D, Sturm M (2005) Differential dissolution of Lake Baikal diatoms: correction factors and implications for palaeoclimatic reconstruction. Glob Planet Change 46:75-86

Bennike O (2000) Palaeoecological studies of Holocene lake sediments from West Greenland. Palaeogeogr Palaeoclimatol Palaeoecol 155:285-304

Bertilsson S, Burgin A, Carey CC, Fey SB, Grossart H-P, Grubisic LM, Jones ID, Kirillin G, Lennon JT, Shade A (2013) The under-ice microbiome of seasonally frozen lakes. Limnol Oceanogr 58:1998-2012

Blanchet FG, Legendre P, Borcard D (2008) Modelling directional spatial processes in ecological data. Ecol Model 215:325-336
Blinn DW, Fredericksen A, Korte V (1980) Colonization rates and community structure of diatoms on three different rock substrata in a lotic system. Brit Phycol J 15:303-310

Bonilla S, Villeneuve V, Vincent WF (2005) Benthic and planktonic algal communities in a High Arctic lake: pigment structure and contrasting responses to nutrient enrichment. J Phycol 41:1120-1130

Borcard D, Legendre P, Drapeau P (1992) Partialling out the spatial component of ecological variation. Ecology 73:1045-1055

Bothwell ML, Sherbot DM, Pollock CM (1994) Ecosystem response to solar ultraviolet-B radiation: influence of trophic-level interactions. Science 265:97-100

Bouchard G, Gajewski K, Hamilton P (2004) Freshwater diatom biogeography in the Canadian Arctic Archipelago. J Biogeogr 31:1955-1973

Bradley RS, Retelle MJ, Ludlam SD, Hardy DR, Zolitschka B, Lamoureux SF, Douglas MSV (1996) The Taconite Inlet Lakes Project: a systems approach to paleoclimatic reconstruction. J Paleolimnol 16:97-110

Brodersen KP, Anderson NJ (2002) Distribution of chironomids (Diptera) in low arctic West Greenland lakes: trophic conditions, temperature and environmental reconstruction. Freshw Biol 47:1137-1157

Cameron N (1995) The representation of diatom communities by fossil assemblages in a small acid lake. J Paleolimnol 14:185-223

Cameron N, Birks H, Jones V, Berges F, Catalan J, Flower R, Garcia J, Kawecka B, Koinig K, Marchetto A (1999) Surface-sediment and epilithic diatom $\mathrm{pH}$ calibration sets for remote European mountain lakes (AL: PE Project) and their comparison with the Surface Waters Acidification Programme (SWAP) calibration set. J Paleolimnol 22:291-317

Cantonati M, Scola S, Angeli N, Guella G, Frassanito R (2009) Environmental controls of epilithic diatom depth-distribution in an oligotrophic lake characterized by marked water-level fluctuations. Eur J Phycol 44:15-29

Catalan J, Ventura M, Brancelj A, Granados I, Thies H, Nickus U, Korhola A, Lotter A, Barbieri A, Stuchlík E (2002) Seasonal ecosystem variability in remote mountain lakes: implications for detecting climatic signals in sediment records. J Paleolimnol 28:25-46

DeYoe RH, Lowe RL, Marks JC (1992) Effects of nitrogen and phosphorus on the endosymbiont load of Rhopalodia gibba and Epithemia turgida (Bacillariophyceae) 1. J Phycol 28:773-777

Douglas MSV, Smol JP (1999) Freshwater diatoms as indicators of environmental change in the High Arctic. In: Stoermer E, Smol JP (eds) The diatoms: applications for the environment and earth sciences. Cambridge University Press, Cambridge, pp 227-244

Douglas MSV, Smol JP, Blake W Jr (1994) Marked post-18th century environmental change in high-arctic ecosystems. Science 226:416-419

Douglas MSV, Ludlam S, Feeney S (1996) Changes in diatom assemblages in Lake C2 (Ellesmere Island, Arctic Canada): response to basin isolation from the sea and to other environmental changes. J Paleo 16:217-226

Dray S, Legendre P, Peres-Neto PR (2006) Spatial modelling: a comprehensive framework for principal coordinate 
analysis of neighbour matrices (PCNM). Ecol Model 196:483-493

Finkelstein S, Gajewski K (2008) Responses of Fragilarioiddominated diatom assemblages in a small Arctic lake to Holocene climatic changes, Russell Island, Nunavut, Canada. J Paleolimnol 40:1079-1095

Hall RI, Leavitt PR, Quinlan R, Dixit AS, Smol JP (1999) Effects of agriculture, urbanization and climate on water quality in the Northern Great Plains. Limnol Oceanogr 44:739-756

Hogan EJ, McGowan S, Anderson NJ (2014) Nutrient limitation of periphyton growth in freshwater lakes in South West Greenland. Polar Biol 37:1331-1342

Jones VJ, Birks HJB (2004) Lake-sediment records of recent environmental change on Svalbard: results of diatom analysis. J Paleolimnol 31:445-466

Jones JI, Young JO, Haynes GM, Moss B, Eaton JW, Hardwick KJ (2000) Do submerged aquatic plants influence their periphyton to enhance the growth and reproduction of invertebrate mutualists? Oecologia 120:463-474

Jones V, Solovieva N, Self A, McGowan S, Rosén P, Salonen J, Seppä H, Väliranta M, Parrott E, Brooks S (2011) The influence of Holocene tree-line advance and retreat on an arctic lake ecosystem: a multi-proxy study from Kharinei Lake, North Eastern European Russia. J Paleolimnol 46:123-137

Juggins S (2013) Quantitative reconstructions in palaeolimnology: new paradigm or sick science? Quatern Sci Rev 64:20-32

Keatley BE, Douglas MS, Smol JP (2006) Early-20th century environmental changes inferred using subfossil diatoms from a small pond on Melville Island, NWT, Canadian high Arctic. Hydrobiologia 553:15-26

Keatley BE, Douglas MS, Smol JP (2008) Prolonged ice cover dampens diatom community responses to recent climatic change in high Arctic lakes. Arct Antarct Alp Res 40:364-372

Kelly MG, Bennion H, Cox EJ, Goldsmith B, Jamieson J, Juggins S, Mann DG, Telford RJ (2005) Common freshwater diatoms of Britain and Ireland: an interactive key. Environment Agency, Bristol

Kelly M, Bennion H, Burgess A, Ellis J, Juggins S, Guthrie R, Jamieson J, Adriaenssens V, Yallop M (2009) Uncertainty in ecological status assessments of lakes and rivers using diatoms. Hydrobiologia 633:5-15

King L, Barker P, Jones RI (2000) Epilithic algal communities and their relationship to environmental variables in lakes of the English Lake District. Freshw Biol 45:425-442

King L, Clarke G, Bennion H, Kelly M, Yallop M (2006) Recommendations for sampling littoral diatoms in lakes for ecological status assessments. J Appl Phycol 18:15-25

Knudson BM, Kipling T (1957) Ecology of the epiphytic diatom Tabellaria flocculosa (Roth) Kutz. var. flocculosa in three English lakes. J Ecol 45:93-112

Krammer K, Lange-Bertalot H (1986-1991) Süsswasser flora von Mitteleuropa, 4 volumes. Band 2. Gustav Fischer Verlag, Stuttgart

Law A, Anderson N, McGowan S (2015) Spatial and temporal variability of lake ontogeny in south-western Greenland. Quatern Sci Rev 126:1-16
Leavitt PR, Brock CS, Ebel C, Patoine A (2006) Landscapescale effects of urban nitrogen on a chain of freshwater lakes in central North America. Limnol Oceanogr 51:2262-2277

Leps J, Smilauer P (2003) Multivariate analysis of ecological data using CANOCO. Cambridge University Press, Cambridge

Lim DS, Douglas MS, Smol JP (2001a) Diatoms and their relationship to environmental variables from lakes and ponds on Bathurst Island, Nunavut, Canadian High Arctic. Hydrobiologia 450:215-230

Lim DS, Kwan C, Douglas MS (2001b) Periphytic diatom assemblages from Bathurst Island, Nunavut, Canadian High Arctic: an examination of community relationships and habitat preferences. J Phycol 37:379-392

Lim DS, Smol JP, Douglas MS (2007) Diatom assemblages and their relationships to lakewater nitrogen levels and other limnological variables from 36 lakes and ponds on Banks Island, NWT, Canadian Arctic. Hydrobiologia 586:191-211

Liversidge AC (2012) The role of climate in determining the ontogeny trends of low Arctic lakes, south-western Greenland. Ph.D. thesis, Loughborough University

McCormick PV, Stevenson RJ (1991) Mechanisms of benthic algal succession in lotic environments. Ecology 72:1835-1848

McGowan S, Ryves DB, Anderson NJ (2003) Holocene records of effective precipitation in West Greenland. The Holocene 13:239-249

McGowan S, Barker P, Haworth EY, Leavitt PR, Maberly SC, Pates J (2012) Humans and climate as drivers of algal community change in Windermere since 1850 . Freshw Biol 57:260-277

McGowan S, Anderson NJ, Edwards ME, Langdon PG, Jones VJ, Turner S, van Hardenbroek M, Whiteford E, Wiik E (2016) Long-term perspectives on terrestrial and aquatic carbon cycling from palaeolimnology. Wiley Interdisciplinary Reviews: Water 3:211-234

Michelutti N, Holtham AJ, Douglas MS, Smol JP (2003) Periphytic diatom assemblages from ultra-oligotrophic and UV transparent lakes and ponds on Victoria Island and comparisons with other diatom surveys in the Canadian Arctic. J Phycol 39:465-480

Michelutti N, Smol JP, Douglas MS (2006) Ecological characteristics of modern diatom assemblages from Axel Heiberg Island (High Arctic Canada) and their application to paleolimnological inference models. Botany 84:1695-1713

Michelutti N, Douglas MS, Smol JP (2007a) Evaluating diatom community composition in the absence of marked limnological gradients in the high Arctic: a surface sediment calibration set from Cornwallis Island (Nunavut, Canada). Polar Biol 30:1459-1473

Michelutti N, Hermanson MH, Smol JP, Dillon PJ, Douglas MS (2007b) Delayed response of diatom assemblages to sewage inputs in an Arctic lake. Aquat Sci 69:523-533

Miller MC, DeOliveira P, Gibeau GG (1992) Epilithic diatom community response to years of $\mathrm{PO} 4$ fertilization: Kuparuk River, Alaska (68N Lat.). Toolik Lake. Springer, pp 103-119 
Moore J (1974) Benthic algae of Southern Baffin Island: II. The epipelic communities in temporary ponds. $\mathrm{J}$ Ecol 62:809-819

Morabito G, Oggioni A, Panzani P (2003) Phytoplankton assemblage at equilibrium in large and deep subalpine lakes: a case study from Lago Maggiore (N. Italy). In: Naselli-Flores L, Padisák J, Dokulil MT (eds) Phytoplankton and equilibrium concept: the ecology of steadystate assemblages. Springer, pp. 37-48

Perren B, Anderson NJ, Douglas MV, Fritz S (2012) The influence of temperature, moisture, and eolian activity on Holocene lake development in West Greenland. J Paleolimnol 48:223-239

Peterson CG (1996) Response of benthic algal communities to natural physical disturbance. In: Stevenson RJ, Bothwell ML, Lowe RL (eds) Algal ecology: freshwater benthic ecosystems. Academic Press, San Diego, pp 375-401

Pizarro H, Allende L, Bonaventura SM (2004) Littoral epilithon of lentic water bodies at Hope Bay, Antarctic Peninsula: biomass variables in relation to environmental conditions. Hydrobiologia 529:237-250

Pla S, Anderson NJ (2005) Environmental factors correlated with chrysophyte cyst assemblages in low arctic lakes of Southwest Greenland. J Phycol 41:957-974

Pokrovsky OS, Shirokova LS, Kirpotin SN, Audry S, Viers J, Dupre B (2011) Effect of permafrost thawing on organic carbon and trace element colloidal speciation in the thermokarst lakes of western Siberia. Biogeosciences 3:565-583

Quesada A, Fernández-Valiente E, Hawes I, Howard-Williams C, Vincent WF (2008) Benthic primary production in polar lakes and rivers. In: Laybourn-Parry J, Vincent WF (eds) Polar lakes and rivers: limnology of Arctic and Antarctic aquatic ecosystems. Oxford University Press, Oxford, pp 179-195

Reuss NS, Hamerlík L, Velle G, Michelsen A, Pedersen O, Brodersen KP (2014) Microhabitat influence on chironomid community structure and stable isotope signatures in West Greenland lakes. Hydrobiologia 730:59-77

Ruhland K, Paterson AM, Smol JP (2008) Hemispheric-scale patterns of climate-related shifts in planktonic diatoms from North American and European lakes. Glob Change Biol 14:2740-2754

Ryves DB, McGowan S, Anderson NJ (2002) Development and evaluation of a diatom-conductivity model from lakes in West Greenland. Freshw Biol 47:995-1014

Ryves DB, Jewson DH, Sturm M, Battarbee RW, Flower RJ, Mackay AW, Granin NG (2003) Qunatitative and qualitative relationships between planktonic diatom communities and diatom assemblages in sedimenting material and surface sediments in Lake Baikal, Siberia. Limnol Oceanogr 48:1643-1661

Ryves DB, Battarbee RW, Juggins S, Fritz SC, Anderson NJ (2006) Physical and chemical predictors of diatom dissolution in freshwater and saline lake sediments in North America and West Greenland. Limnol Oceanogr 51:1355-1368

Ryves DB, Anderson NJ, Flower RJ, Rippey B (2013) Diatom taphonomy and silica cycling in two freshwater lakes and their implications for inferring past lake productivity. J Paleolimnol 49:411-430

Saros JE, Northington RM, Anderson DS, Anderson NJ (2016) A whole-lake experiment confirms a small centric diatom species as an indicator of changing lake thermal structure. Limnol Oceanogry Lett 1:27-35

Smith DJ, Underwood GJ (1998) Exopolymer production by intertidal epipelic diatoms. Limnol Oceanogr 43:1578-1591

Smol JP, Wolfe AP, Birks HJB, Douglas MS, Jones VJ, Korhola A, Pienitz R, Rühland K, Sorvari S, Antoniades D (2005) Climate-driven regime shifts in the biological communities of arctic lakes. Proc Natl Acad Sci USA 102:4397-4402

Spaulding SA, Lubinski DJ, Potapova M (2010) Diatoms of the United States. Available at Westerndiatoms.colorado.edu

Štefková E (2006) Epilithic diatoms of mountain lakes of the Tatra Mountains (Slovakia). Biologia 61:S101-S108

Stevens LR, Stone JR, Campbell J, Fritz SC (2006) A 2200-yr record of hydrologic variability from Foy Lake, Montana, USA, inferred from diatom and geochemical data. Quatern Res 65:264-274

Stevenson RJ, Peterson CG, Kirschtel DB, King CC, Tuchman NC (1991) Density-dependent growth, ecological strategies, and effects of nutrients and shading on benthic diatom succession in streams. J Phycol 27:59-69

Stone JR, Fritz SC (2006) Three-dimensional modeling of lacustrine diatom habitat areas: improving paleolimnological interpretation of planktic: benthic ratios. Limnol Oceanogr 49:1540-1548

Tanaka N, Ohwada K (1988) Decomposition of agar, protein, and organic phosphate by marine epiphytic diatoms. Bull Jpn Soc Sci Fish (Japan) 54:725-727

Ter Braak CJF, Smilauer P (2012) CANOCO reference manual and user's guide: software for ordination (version 5.0). Biometris. Wageningen and Ceske Budejojice

Tuchman NC, Schollett MA, Rier ST, Geddes P (2006) Differential heterotrophic utilization of organic compounds by diatoms and bacteria under light and dark conditions. Hydrobiologia 561:167-177

Vadeboncoeur Y, Jeppesen E, Vander Zanden MJ, Schierup HH, Christoffersen K, Lodge DM (2003) From Greenland to green lakes: cultural eutrophication and the loss of benthic pathways in lakes. Limnol Oceanogr 48:1408-1418

Whiteford EJ, McGowan S, Barry C, Anderson NJ (2016) Seasonal and regional controls of phytoplankton production during ice cover and ice free conditions along a climate gradient in SW Greenland. Arct Antarct Alp Res 48:139-159

Willemse NW, van Dam O, van Helvoort P-J, Dankers R, Brommer M, Schokker J, Valstar TE, de Wolf H (2004) Physical and chemical limnology of a subsaline athalassic lake in West Greenland. Hydrobiologia 524:167-192

Wolfe AP, Cooke CA, Hobbs WO (2006) Are current rates of atmospheric nitrogen deposition influencing lakes in the eastern Canadian Arctic? Arct Antarct Alp Res 38:465-476 